\title{
Distribution of manganese species in an oxidative dimerization reaction of a bis-terpyridine mononuclear manganese (II) complex and their heterogeneous water oxidation activities
}

Kosuke Takahashi $^{\text {a) }}$, Hirosato Yamazaki ${ }^{\text {a) }}$, Masayuki Yagi ${ }^{\text {a),b)* }}$

a) Department of Materials Science and Technology, Faculty of Engineering \& Center for Transdisciplinary Research, Niigata University, 8050 Ikarashi-2, Niigata 950-2181, Japan.

b) PRESTO, Japan Science and Technology Agency (JST), 4-1-8 Honcho, Kawaguchi, Saitama 332-0012, Japan. (PRESTO: Precursory Research for Embryonic Science and Technology)

*E-mail: yagi@eng.niigata-u.ac.jp; Fax: +81-25-262-6790

Keywords: Water oxidation catalyst, manganese complex, Layer compounds, Photosystem II, artificial photosynthesis

Submitted to Journal of Photochemistry and Photobiology B: Biology as Full papers 


\section{Abstract}

Heterogeneous water oxidation catalyses were studied as a synthetic model of oxygen evolving complex (OEC) in photosynthesis using mica adsorbing various manganese species. Distribution of manganese species formed in the oxidative dimerization reaction of $\left[\mathrm{Mn}^{\mathrm{II}}(\text { terpy })_{2}\right]^{2+}\left(\right.$ terpy $=2,2^{\prime}: 6^{\prime}, 2^{\prime \prime}$-terpyridine $)\left(\mathbf{1}^{\prime}\right)$ with various oxidants in water was revealed. 1' was stoichiometrically oxidized to form di- $\mu$-oxo dinuclear manganese complex, $\left[\left(\mathrm{OH}_{2}\right)\left(\text { terpy) } \mathrm{Mn}^{\mathrm{III}}(\mu-\mathrm{O}){ }_{2} \mathrm{Mn}^{\mathrm{IV}}(\text { terpy })\left(\mathrm{OH}_{2}\right)\right]^{3+}\right.$ (1) by $\mathrm{KMnO}_{4}$ as an oxidant. When Oxone and $\mathrm{Ce}(\mathrm{IV})$ oxidants were used, the further oxidation of $\mathbf{1}$ to $\left[\left(\mathrm{OH}_{2}\right)\left(\text { terpy) } \mathrm{Mn}^{\mathrm{IV}}(\mu-\mathrm{O})_{2} \mathrm{Mn}^{\mathrm{IV}} \text { (terpy) }\left(\mathrm{OH}_{2}\right)\right]^{4+}(\mathbf{2})\right.$ was observed after the oxidative dimerization reaction of $\mathbf{1}^{\prime}$. The mica adsorbates with various composition of $\mathbf{1}^{\prime}, \mathbf{1}$ and $\mathbf{2}$ were prepared by adding mica suspension to the various oxidant-treated solutions followed by filtration. The heterogeneous water oxidation catalysis by the mica adsorbates was examined using a Ce(IV) oxidant. The observed catalytic activity of the mica adsorbates corresponded to a content of $\mathbf{1}\left(\mathbf{1}_{\mathrm{ads}}\right)$ adsorbed on mica for $\mathrm{KMnO}_{4^{-}}$and Oxone-treated systems, indicating that $\mathbf{1}^{\prime}\left(\mathbf{1}^{\prime}\right.$ ads $)$ and $\mathbf{2}\left(\mathbf{2}_{\text {ads }}\right)$ adsorbed on mica do not work for the catalysis. The kinetic analysis suggested that $\mathbf{1}_{\text {ads }}$ works for the catalysis through cooperation with adjacent $\mathbf{1}_{\text {ads }}$ or $\boldsymbol{2}_{\text {ads }}$, meaning that $\boldsymbol{2}_{\text {ads }}$ assists the cooperative catalysis by $\mathbf{1}_{\text {ads }}$ though $\boldsymbol{2}_{\text {ads }}$ is not able to work for the catalysis alone. For the $\mathrm{Ce}(\mathrm{IV})$-treated system, $\mathrm{O}_{2}$ evolution was hardly observed although the sufficient amount of $\mathbf{1}_{\text {ads }}$ was contained in the mica adsorbates. This was explained by the impeded penetration of $\mathrm{Ce}(\mathrm{IV})$ ions (as an oxidant for water oxidation) into mica by $\mathrm{Ce}^{3+}$ cations (generated in oxidative dimerization of $\mathbf{1}^{\prime}$ ) co-adsorbed with $\mathbf{1}_{\text {ads. }}$. 


\section{Introduction}

For photosynthesis in nature, $\mathrm{O}_{2}$ evolution from water is catalyzed by OEC composed of a tetranuclear manganese cluster. Recent X-ray diffraction[1-5] and extended X-ray absorption fine structure (EXAFS)[6, 7] studies have revealed the detailed structure of OEC. The crystal structure of PS II at a resolution of $1.9 \AA$ displayed that the tetramanganese cluster $\left(\mathrm{Mn}_{4} \mathrm{CaO}_{5}\right)$ containing an asymmetric $\mathrm{Mn}_{3} \mathrm{CaO}_{4}$ cubane core is located together with all of their ligands in the OEC center,[5] and very recently the core structure was refined based on a 'radiation-damage-free' structure of PSII determined using femtosecond X-ray pulses [8].

Many synthetic manganese complexes as an OEC model have been synthesized for X-ray crystallography, EXAFS, electron paramagnetic resonance (EPR), and magnetic susceptibility studies to provide important insights into the structure of OEC in PS II.[9-21] Although manganese complexes have thus made significant contributions to the structure and the oxidation states of OEC, very limited manganese complexes act as a functional model that is capable of catalyzing water oxidation.[22-37] Molecular aspects and activities of synthetic catalysts for water oxidation have generally been investigated in a homogeneous solution system to gain essential aspects of the catalysts, although the OEC center is confined in heterogeneous protein matrixes. Kaneko et al reported pioneering works on heterogeneous water oxidation catalysis by manganese and ruthenium complexes on layer compounds in the late 1980s.[38, 39]

$\mathrm{O}_{2}$ evolution by $\mathbf{1}$ in reactions with oxygen donor agents in a homogeneous solution were first reported.[22, 23] We reported the heterogeneous water oxidation catalysis of $\mathbf{1}_{\mathrm{ads}}$ on layer compounds such as kaolin, mica and montmorillonite (Mt).[26, 40-42] The kinetic analysis of $\mathrm{O}_{2}$ evolution suggested that the catalysis requires cooperation of two 
equivalents of $\mathbf{1}_{\mathrm{ads}}$ on layer compounds. The heterogeneous catalytic activity of the derivatives with $\mathrm{R}$-terpy ligands $(\mathrm{R}=$ butoxy, propoxy, ethoxy, methoxy, methyl, methylthio, chloro and pyridyl) are quite different, showing that the catalytic activity strongly depends on the structure of complexes adsorbed [43]. We reported that UV-visible diffuse reflectance (DR) spectra, Mn K-edge X-ray absorption near edge structure (XANES) and EXAFS spectra of $\mathbf{1}_{\mathrm{ads}}$ on Mt in supporting information of the literature [26]. Although the DR spectrum changed when 1 was adsorbed on Mt, the

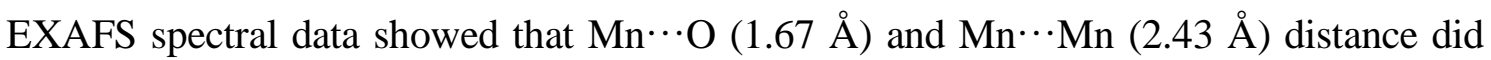
not considerably change. The Mn K-edge for $\mathbf{1}_{\text {ads }}$ on Mt shifted to a higher energy region versus that for $\mathbf{1}$ as a powder[26], suggesting that $\mathbf{1}$ is partially oxidized when adsorbed on Mt. We further demonstrated that the XANES spectra of $\mathbf{1}_{\text {ads }}$ on Mt hardly changed before and after water oxidation catalysis for 30 min using Ce(IV). Very recently, Najafpour et al also reported that the XANES and XAFS data of $\mathbf{1}_{\text {ads }}$ on Mt [44], which are inconsistent with our results reported earlier [26]. Their XANES data suggested that a mean oxidation state (3.5) of $\mathbf{1}$ was reduced to 2.6 (of $\mathbf{1}_{\mathrm{ads}}$ ) when $\mathbf{1}$ was adsorbed on Mt from the lower energy shift of the Mn K-edge for $\mathbf{1}_{\text {ads }}$ on Mt. Their XAFS data provided the longer $\mathrm{Mn} \cdots \mathrm{O} / \mathrm{N}(1.80$ and $2.03 \AA)$ and $\mathrm{Mn} \cdots \mathrm{Mn}(2.72 \AA)$ distances for $\mathbf{1}_{\mathrm{ads}}$ on Mt, compared with those reported earlier[26]. By treatment with $\mathrm{Ce}(\mathrm{IV}) \mathbf{1}_{\mathrm{ads}}$ on $\mathrm{Mt}$ was re-oxidized to 3.5 of the mean oxidation state and the $\mathrm{Mn} \cdots \mathrm{O}(1.87 \AA)$ and $\mathrm{Mn} \cdots \mathrm{Mn}$ (2.86, 3.10, 3.81, $4.99 \AA)$ distance were lengthened in their report. Najafpour et al also mentioned that manganese clay adsorbates with similar water oxidation activity can be obtained starting (not from 1) from simple Mn salts, e.g., $\mathrm{Mn}\left(\mathrm{NO}_{3}\right)_{2}$, despite being treated with $\mathrm{MnO}_{4}{ }^{-}$in basic conditions[44, 45]. This result is quite different from our previous 
report that layer compounds containing $\mathrm{Mn}^{2+}$ or $\mathrm{Mn}^{3+}$ ions does not work for water oxidation at all.[26, 40-42] They suggested from their X-ray absorption spectroscopic and $\mathrm{O}_{2}$ evolution data that $\mathbf{1}$ is transformed on $\mathrm{Mt}$ into layered type manganese-oxide particles which are the actual water oxidation catalyst. The manganese-based Mt adsorbate samples prepared by Najafpour et al are different from those prepared in our group, possibly due to difference of a sort in a method. Thus, the mechanism of water oxidation by $\mathbf{1}_{\mathrm{ads}}$ on the layer compounds is still interesting issue.

1 can be synthesized by oxidative dimerization of $\mathrm{Mn}(\text { terpy })_{2}{ }^{2+}\left(\mathbf{1}^{\prime}\right)$ or $\mathrm{Mn}($ terpy $) \mathrm{Cl}_{2}$ precursor.[46, 47] The oxidative dimerization of $\mathbf{1}$ ' in an aqueous solution involves initial one-electron oxidation to form $\mathrm{Mn}$ (terpy) ${ }_{2}{ }^{3+}$ intermediate and subsequent and rapid disproportionation of $\mathrm{Mn}$ (terpy) ${ }_{2}{ }^{3+}$ to form 1 [48]. However, there is no report on quantitatively-determined oxidative dimerization reactions of $\mathbf{1}$ ' by chemical oxidants. Herein we investigate oxidative dimerization reactions of 1' using different kinds of oxidants $\left(\mathrm{KMnO}_{4}\right.$, Oxone, $\left.\mathrm{Ce}^{\mathrm{IV}}\right)$ in water to quantitatively determine the solution composition of manganese species formed in the reactions. The solutions with different composition of manganese species are useful to easily prepare a large variety of manganese species-based adsorbates of layer compounds. We examine the heterogeneous water oxidation activity of mica adsorbates with different composition of manganese species.

\section{Experimental Section}

Materials. Oxone $\left(\mathrm{KHSO}_{5} \cdot 0.5 \mathrm{KHSO}_{4} \cdot 0.5 \mathrm{~K}_{2} \mathrm{SO}_{4}\right), \mathrm{KMnO}_{4}$ and $\mathrm{Ce}\left(\mathrm{NH}_{4}\right)_{2}\left(\mathrm{NO}_{3}\right)_{6}($ Wako Pure Chemical Industries, Ltd.), terpy (Aldrich Co., Inc.) were purchased. Somasif (ME-100) of mica was given from Co-op Chemical Co., Inc., Japan. All the chemicals are 
used as received. 1' $\left(\mathrm{NO}_{3}\right)_{2}$ was prepared according to the literatures.[48]

\section{Preparation of mica adsorbing manganese species.}

An aqueous solution $(1 \mathrm{mM}, 10 \mathrm{ml} . \mathrm{pH}=3.0)$ containing $\mathbf{1}^{\prime}\left(\mathrm{NO}_{3}\right)_{2}$ and various amounts of the oxidants was added to an aqueous mica suspension (50 mg mica, $5 \mathrm{ml}, \mathrm{pH}$ $=3.0)$ to adsorb manganese species from the solution onto mica. The suspension was filtrated after stirring for $30 \mathrm{~min}$, and then dried under vacuum to yield mica adsorbing manganese species. The amount of manganese species adsorbed was calculated by the UV-visible absorption spectral change of the solution before and after adding mica.

\section{Measurements.}

The titration of the aqueous $\mathbf{1}^{\prime}\left(\mathrm{NO}_{3}\right)_{2}$ solution with various oxidants (Oxone, $\left.\mathrm{KMnO}_{4}, \mathrm{Ce}\left(\mathrm{NH}_{4}\right)_{2}\left(\mathrm{NO}_{3}\right)_{6}\right)$ was performed as follows. An adequate small portion of an aqueous solution $(0.1 \mathrm{M})$ of an aqueous oxidant solution was added to an aqueous $\mathbf{1}$ solution $(1 \mathrm{mM}, 4.0 \mathrm{ml}, \mathrm{pH}=3.0)$. The UV-visible absorption spectral change of the solution was measured in a quartz cell using a photodiode array spectrophotometer (Shimadzu, Multispec-1500). UV-vis diffuse reflectance (DR) spectra were measured using a spectrophotometer (JASCO Inc., V-670) with an integrating sphere (ISN-723). The flow electrolysis was performed using a flow electrolysis system (HX-201, Hokuto Denko Co., Ltd.). Electrolysis was conducted at $1.2 \mathrm{~V}$ vs $\mathrm{Ag} / \mathrm{AgCl}$ using an electrolyte

solution of $0.1 \mathrm{M} \mathrm{KNO}_{3} \cdot \mathrm{O}_{2}$ evolution experiments were performed as follows. An aqueous solution $(0.1 \mathrm{M}, 100 \mu \mathrm{l})$ of $\mathrm{Ce}\left(\mathrm{NH}_{4}\right)_{2}\left(\mathrm{NO}_{3}\right)_{6}$ was added to the aqueous suspension $(1.9 \mathrm{ml}, \mathrm{pH}=1.0)$ containing $10 \mathrm{mg}$ of mica adsorbing manganese species. 
The amount of $\mathrm{O}_{2}$ evolved was measured in a liquid phase using a Clark type $\mathrm{O}_{2}$ analyzer (Hansatech Instruments, Oxygraph OXYG1 and DW1/AD unit).

\section{Results and discussion}

\section{Titration of a 1' solution with a $\mathrm{KMnO}_{4}$ oxidant.}

The UV-visible absorption spectral change in the reaction of $\mathbf{1}^{\prime}$ with $\mathrm{KMnO}_{4}$ is shown in Figure 1. 1' does not exhibit any absorption band over $500 \mathrm{~nm}$ (red spectrum in Figure 1A). The absorption bands at 552 and $655 \mathrm{~nm}$ appeared by addition of $\mathrm{KMnO}_{4}$ (shown by green spectra), indicating formation of $\mathbf{1}$. The absorption bands at $552 \mathrm{~nm}$ and $655 \mathrm{~nm}$ are assigned to d-d transition and oxygen-to-manganese charge-transfer bands for the $\mathrm{Mn}^{\mathrm{III}}(\mu-\mathrm{O})_{2} \mathrm{Mn}^{\mathrm{IV}}$ core, respectively.[49-51] As the amount of $\mathrm{KMnO}_{4}$ added increased from 0 to 0.5 equivalent (eq) vs the 1' amount, both the absorbances at $552 \mathrm{~nm}$ and 655 $\mathrm{nm}$ increased linearly, as shown in Figure 1B. The slopes of the linear plots for $552 \mathrm{~nm}$ and $655 \mathrm{~nm}$ are consistent with the molar absorption coefficients of 605 and $600 \mathrm{M}^{-1} \mathrm{~cm}^{-1}$ at the wavelength of $\mathbf{1}$, respectively [43]. Above 0.5 eq of $\mathrm{KMnO}_{4}$, the slopes of the absorbance change at 552 and $655 \mathrm{~nm}$ changed. The difference spectrum between 0.5 eq and 1.0 eq is agreement with the $\mathrm{UV}$-visible absorption spectrum of $\mathrm{MnO}_{4}{ }^{-}$ion, showing that the absorption spectral change (shown by purple in Figure $1 \mathrm{~A}$ ) above 0.5 eq is due to a mere concentration increase of $\mathrm{KMnO}_{4}$.

The titration experiment shows that formation of 1 was saturated at 0.5 eq of $\mathrm{KMnO}_{4}$ and that $\mathbf{1}$ is not further oxidized under the excess $\mathrm{KMnO}_{4}$ conditions. The maximum in situ formation yield of $\mathbf{1}$ at 0.5 eq of $\mathrm{KMnO}_{4}$ was calculated using the molar absorption coefficient $\left(600 \mathrm{M}^{-1} \mathrm{~cm}^{-1}\right)$ at $655 \mathrm{~nm}$ to be $145 \%$ based on 1 '. This overproduction (over 
$100 \%$ ) was explained by regeneration of 1 ' from the liberated terpy ligands and $\mathrm{Mn}^{2+}$ formed by reduction of $\mathrm{KMnO}_{4}$, as shown by eqn $1 \sim 4$.

$$
\begin{aligned}
& 2 \mathbf{1}^{\prime}+4 \mathrm{H}_{2} \mathrm{O} \rightarrow \mathbf{1}+4 \mathrm{H}^{+}+3 \mathrm{e}^{-}+2 \text { terpy } \\
& \mathrm{MnO}_{4}^{-}+8 \mathrm{H}^{+}+5 \mathrm{e}^{-} \rightarrow \mathrm{Mn}^{2+}+4 \mathrm{H}_{2} \mathrm{O} \\
& \mathrm{Mn}^{2+}+2 \text { terpy } \rightarrow \mathbf{1}^{\prime} \\
& 7 \mathbf{1}^{\prime}+8 \mathrm{H}_{2} \mathrm{O}+3 \mathrm{MnO}_{4}^{-}+4 \mathrm{H}^{+} \rightarrow 5 \mathbf{1}+4 \text { terpy }
\end{aligned}
$$

The oxidative dimerization of $\mathbf{1}$ ' to $\mathbf{1}$ is 3 -electron process with liberation of an equivalent of the terpy ligand per $\mathbf{1}^{\prime}$ (eqn 1). $\mathrm{KMnO}_{4}$ is known to act as a 5-electron oxidant to give a $\mathrm{Mn}^{2+}$ ion (eqn 2). The terpy ligands liberated in eqn 1 are immediately coordinated by $\mathrm{Mn}^{2+}$ ions to form 1' (eqn 3), which is also oxidized to $\mathbf{1}$. The total oxidative dimerization reaction of $\mathbf{1}^{\text {' by }} \mathrm{KMnO}_{4}$ is represented by eqn 4 from eqns $1 \sim 3$. The theoretical formation yield of $\mathbf{1}$ based on 1' is $143 \%$ according to eq 4 . The present yield (145\%) of 1 suggests that all the reactions (eqns $1 \sim 3$ ) involved in the oxidative dimerization of 1 ' to $\mathbf{1}$ proceeds stoichiometrically.

The distribution of manganese species formed in the dimerization reaction versus the $\mathrm{KMnO}_{4}$ amount was calculated from the UV-visible absorption spectral change in the $\mathrm{KMnO}_{4}$ titration (Figure 2). The concentrations $\left(\mathrm{c}_{1} / \mathrm{M}\right)$ of $\mathbf{1}$ were calculated from the absorbance and the molar absorption coefficient $\left(600 \mathrm{M}^{-1} \mathrm{~cm}^{-1}\right)$ at $655 \mathrm{~nm}$. The concentrations $\left(c_{1}, / M\right)$ of $\mathbf{1}$, were calculated by the initial concentration $\left(c_{1},{ }^{\text {initial }}=1.0\right.$ $\mathrm{mM}$ ) of $\mathbf{1}$, and $\mathrm{c}_{\mathbf{1}}$ according to $\mathrm{c}_{\mathbf{1}}$, ${ }^{\text {initial }}-7 / 5 \mathrm{c}_{1}$ based on eqn $4 . \mathrm{c}_{1}$ increased linearly with $\mathrm{c}_{\mathbf{1}}$, decreased as the amount of $\mathrm{KMnO}_{4}$ increased up to $0.5 \mathrm{eq}$, and thereafter $\mathrm{c}_{1}$ became constant $(0.75 \mathrm{mM})$ up to 1.0 eq. 


\section{Titration of a 1' solution with an Oxone oxidant.}

The UV-visible absorption spectral change in the reaction of 1' with Oxone is shown in Figure 3A. The absorption bands at 552 and $655 \mathrm{~nm}$ of a sign of formation of 1 increased linearly by addition of $0 \sim 0.4$ eq Oxone (Figure 3B), as it is for the $\mathrm{KMnO}_{4}$ titration. However, the absorbance above $655 \mathrm{~nm}$ decreased by further addition of Oxone with an isosbestic point at $608 \mathrm{~nm}$. The absorbance decrease at $655 \mathrm{~nm}$ could be attributed to the further oxidation of $\mathbf{1}$ to $\mathbf{2}$. It is reported that oxidation of $\mathbf{1}$ to $\mathbf{2}$ is followed by formation of the tetranuclear manganese(IV) complex of dimer-to-dimer.[52] For this reason, the accurate UV-visible absorption spectrum of $\mathbf{2}$ has not be reported so for. However, the formation of the tetranuclear manganese(IV) complex is relatively slow [53]. In order to identify the UV visible absorption spectrum of $\mathbf{2}$, we set up a flow spectroelectrochemical system connected with a photodiode array spectrophotometer to take the UV visible absorption spectrum of fresh electrochemical products quickly (order of second) compared with a bulk electrolysis system (order of minute or hour). For the flow spectroelectrochemical measurement, the applied potential of $1.2 \mathrm{~V}$ vs $\mathrm{Ag} / \mathrm{AgCl}$ was employed because the oxidation wave from $\mathbf{1}$ to $\mathbf{2}$ is $0.977 \mathrm{~V}$ vs $\mathrm{Ag} / \mathrm{AgCl}$ on the $\mathrm{CV}$ of $\mathbf{1}$ in $0.1 \mathrm{M} \mathrm{KNO}_{3}$ electrolyte solution [43]. The follow rate is important for the flow spectroelectrochemical measurement. In the case of the slow flow rate $\left(0.1 \mathrm{ml} \mathrm{min}^{-1}\right)$, the absorption due to tetranuclear manganese(IV) complex was observed in the UV-visible absorption spectrum after electrolysis of the $\mathbf{1}$ solution, whereas it was not observed when the flow rate is faster than $20.0 \mathrm{ml} \mathrm{min}^{-1}$. The UV-visible absorption spectra before and after electrolysis at $1.2 \mathrm{~V}$ vs $\mathrm{Ag} / \mathrm{AgCl}$ (flow rate $20.0 \mathrm{ml} \mathrm{min}^{-1}$ ) are shown in Figure 4. 
The spectrum after electrolysis is almost identical with the spectrum of the titration solution at 0.7 eq Oxone (Figure 3A), suggesting that 2 was subsequently formed by oxidation of $\mathbf{1}$ that is formed by oxidative dimerization of $\mathbf{1}$ ' with Oxone, in contrast to no further reaction of $\mathbf{1}$ in the $\mathrm{KMnO}_{4}$ system.

The distribution of manganese species formed in the dimerization reaction versus the Oxone amount was calculated from the UV-visible absorption spectral change in Oxone titration (Figure 5). $c_{1}$ and the concentrations $\left(c_{2} / M\right)$ of 2 were calculated from the absorbance change using the molar absorption coefficients of $1\left(\left(\varepsilon_{552}\right)_{1}=605,\left(\varepsilon_{655}\right)_{\mathbf{1}}=\right.$ 600, $\left.\left(\varepsilon_{730}\right)_{1}=498 \mathrm{M}^{-1} \mathrm{~cm}^{-1}\right)$ and $2\left(\left(\varepsilon_{552}\right)_{2}=1180,\left(\varepsilon_{655}\right)_{2}=492,\left(\varepsilon_{730}\right)_{2}=306 \mathrm{M}^{-1} \mathrm{~cm}^{-1}\right)$ at respective wavelength (indicated in subscript notations of $\varepsilon$ ) given by the spectroelectrochemical measurement (Figure 5). $\mathrm{c}_{1}$, was calculated by $\mathrm{c}_{1}$, ${ }^{\text {initial }}=1.0 \mathrm{mM}$, $c_{1}$ and $c_{2}$ according to $c_{1}$, ${ }^{\text {initial }}-2\left(c_{1}+c_{2}\right)$. $c_{1}$ increased linearly with $c_{1}$, decreased as the amount of Oxone up to $0.4 \mathrm{eq}$, and thereafter $c_{1}$ decrease with $c_{2}$ increased up to 1.0 eq. The maximum in situ formation yields of 1 and $\mathbf{2}$ were 87\% (at $0.8 \mathrm{eq}$ ) and 91\% (1.4 eq), respectively. The calculated $c_{1}$, value includes $\sim 9 \%$ of the other manganese species particularly at the higher Oxone amounts.

\section{Titration of a 1' solution with a Ce(IV) oxidant.}

When a $\mathrm{Ce}(\mathrm{IV})$ oxidant was used for titration of the 1' solution, the similar UV-visible absorption spectral change to that in the Oxone titration was observed (Figure 6); 1 was formed followed by 2 formation as the Ce(IV) amount increased. The distribution of manganese species formed in the dimerization reaction versus the $\mathrm{Ce}(\mathrm{IV})$ amount was calculated in the same manner as the Oxone system (Figure 7). $c_{1}$ increased 
with the amount of $\mathrm{Ce}(\mathrm{IV})$ from 0 to 5.2 eq. $c_{1}$ decreased with $c_{2}$ increased in the further addition (5.2 $10 \mathrm{eq})$ of $\mathrm{Ce}(\mathrm{IV})$, and $\mathrm{c}_{1}$ and $\mathrm{c}_{2}$ became zero and constant value of 0.74 $\mathrm{mM}$ over 9.4 eq Ce(IV), respectively. The maximum in situ formation yield of $\mathbf{1}$ and $\mathbf{2}$ was $67 \%$ at 5.2 eq and $74 \%$ at 9.4 eq, respectively.

The maximum yields of $\mathbf{1}$ and $\mathbf{2}$ in the oxidative dimerization reaction of $\mathbf{1}$ ' using various oxidants are summarized in Table 1 . For the yield of $\mathbf{1}, \mathrm{KMnO}_{4}(145 \%$ at $0.5 \mathrm{eq})$ is a favorable oxidant because 1) $\mathbf{1}$ is stoichiometrically formed, 2) the liberated terpy ligands are reused for formation of 1' through complexation with $\mathrm{Mn}^{2+}$ (via $\mathrm{KMnO}_{4}$ ), and 3) the further oxidation of $\mathbf{1}$ to $\mathbf{2}$ does not proceed. When Oxone was used, $\mathbf{1}$ and $\mathbf{2}$ were obtained in nearly quantitative yields of $87 \%$ at 0.8 eq and $91.4 \%$ at 1.4 eq, respectively. When Ce(IV) was used, the maximum yields (67\% and 74\%) of $\mathbf{1}$ and $\mathbf{2}$ are lower than those for Oxone, and the much larger amount (5.2 eq and 9.4 eq) of Ce(IV) was required for the maximum yields of $\mathbf{1}$ and $\mathbf{2}$. The electron oxidant of Ce(IV) is relatively unsuitable for $\mathbf{1}$ and $\mathbf{2}$ formations to oxygen atom donating agents of Oxone.

\section{Preparation and characterization of mica adsorbates.}

To investigate influence of manganese species adsorbed onto mica on the heterogeneous catalytic activity, the various mica adsorbates were prepared by adding mica suspensions to the solutions with different manganese composition of $\mathbf{1}, \mathbf{1}$ and $\mathbf{2}$ formed by various oxidant-treatments. For the solution treated using $\mathrm{KMnO}_{4}$ or Oxone, all the manganese complexes were adsorbed onto mica by cation exchange with $\mathrm{Na}^{+}$ under the conditions employed. For the $\mathrm{Ce}(\mathrm{IV})$-treated solution, $\mathrm{Ce}^{3+}$ cations generated by reduction of $\mathrm{Ce}(\mathrm{IV})$ are co-adsorbed with the manganese complexes. The UV-visible DR 
spectrum of the mica adsorbate prepared from the solution mainly containing $\mathbf{1}$ (treated with 0.8 eq Oxone) exhibited an intense shoulder at $410 \mathrm{~nm}$ (green line in Figure 8), which is very similar to that of the mica adsorbate prepared using isolated 1 [40]. The similar DR spectra were observed for the $\mathrm{KMnO}_{4}(0.5 \mathrm{eq})$ and $\mathrm{Ce}(\mathrm{IV})(5.2 \mathrm{eq})$ systems. However, $\mathbf{1}_{\mathrm{ads}}$ on mica is not intact as reported earlier [40]. The DR spectrum of the mica adsorbate prepared from the solution mainly containing 2 (treated with 1.4 eq Oxone) showed a shoulder at $550 \mathrm{~nm}$ (blue line in Figure 8). It is considerably different from the absorption spectrum of $\mathbf{2}$ in water (Figure 3A and 4), suggesting that $\mathbf{2}_{\text {ads }}$ on mica is not intact although it is not fully characterized yet. The different DR spectrum between $\mathbf{1}_{\text {ads }}$ and $\boldsymbol{2}_{\text {ads }}$ in Figure 8 suggests that the manganese species on mica is certainly different between the cases prepared from $\mathbf{1}$ and $\mathbf{2}$ solutions.

\section{Heterogeneous water oxidation by mica adsorbates.}

The heterogeneous catalytic activities of various mica adsorbates for water oxidation were examined using a $\mathrm{Ce}(\mathrm{IV})$ oxidant. The time courses of the amount of $\mathrm{O}_{2}$ evolved by water oxidation for the mica adsorbates prepared from the $\mathrm{KMnO}_{4}$-treated solutions are shown in Figure 9. The amount of $\mathrm{O}_{2}$ evolved increased with an increase $(0 \sim 0.5$ eq) of the amount of $\mathrm{KMnO}_{4}$ added for oxidative dimerization of 1'. The initial $\mathrm{O}_{2}$ evolution rates $\left(\mathrm{v}_{\mathrm{O} 2} / \mathrm{mol} \mathrm{s}^{-1}\right)$ were calculated from the initial slopes of the $\mathrm{O}_{2}$ evolution time courses. The plots of $\mathrm{v}_{\mathrm{O} 2}$ vs the amount of $\mathrm{KMnO}_{4}$ are shown in Figure 2 together with distribution of manganese species in the $\mathrm{KMnO}_{4}$-treated solution. The $\mathrm{v}_{\mathrm{O} 2}$ data gave an upward curve in $\mathrm{KMnO}_{4}$ amount range of $0 \sim 0.5$ eq where $\mathrm{c}_{1}$ increased linearly with the amount of $\mathrm{KMnO}_{4}$, and the $\mathrm{v}_{\mathrm{O} 2}$ value became constant coincident with $\mathrm{c}_{1}$ above 0.5 eq. 
To reveal the catalytic activity per one equivalent of $\mathbf{1}_{\mathrm{ads}}, \mathrm{v}_{\mathrm{O} 2}$ was normalized by the amount of $\mathbf{1}_{\mathrm{ads}}\left(\mathrm{n}_{1} / \mathrm{mol}\right)$ to define the apparent turnover frequency $\left(\mathrm{k}_{\mathrm{app}} / \mathrm{s}^{-1}\right)$ as $\mathrm{k}_{\mathrm{app}}=\mathrm{v}_{\mathrm{O} 2}$ / $n_{1}$. The plots of $k_{a p p} v s n_{1}$ gave a straight line with the significant slope passing through the near origin (Figure 10A). The significant slope and the almost zero intercept suggest that $\mathrm{O}_{2}$ evolution is a second order with respect to $\mathbf{1}_{\text {ads }}$. This result is consistent with the cooperative catalysis by two equivalences of $\mathbf{1}_{\text {ads }}$, as reported previously $[26,40]$. The $\mathrm{v}_{\mathrm{O} 2}$ data clearly show that $\mathbf{1}_{\text {ads }}$ works for water oxidation catalysis, whereas $\mathbf{1}^{\prime}\left(\mathbf{1}_{\text {ads }}\right.$ ) adsorbed on mica does not do so.

For the Oxone-treated system, the plots of $\mathrm{v}_{\mathrm{O} 2}$ vs the amount of Oxone was shown in Figure 5 together with distribution of manganese species. The $\mathrm{v}_{\mathrm{O} 2}$ data changed significantly although the total manganese amount adsorbed onto mica is the same. The $\mathrm{v}_{\mathrm{O} 2}$ data gave upward curve in an Oxone amount range of $0 \sim 0.8$ eq, and thereafter passing the maximum value at $0.4 \mathrm{eq}, \mathrm{v}_{\mathrm{O} 2}$ decreased with the Oxone amount to be zero above 0.7 eq. The amount $(0.8 \mathrm{eq})$ of Oxone for the maximum $\mathrm{v}_{\mathrm{O} 2}$ is in agreement with that for the maximum $c_{1}$, supporting that $\mathbf{1}_{\text {ads }}$ works for water oxidation catalysis. It also suggests that $\mathbf{2}_{\text {ads }}$ does not work for the catalysis, as is the case for $\mathbf{1}^{\prime}$ ads. The reason for inactivity of $\boldsymbol{2}_{\text {ads }}$ might be explained by conversion of $\boldsymbol{2}_{\text {ads }}$ to inactive species, as $\mathbf{2}$ is gradually converted to the tetranuclear manganese(IV) complex in solution $[52,53]$. The UV-visible DR spectrum of the mica adsorbate prepared from the solution mainly containing 2 (blue line in Figure 8) could rather be that of inactive species converted from $\boldsymbol{2}_{\text {ads }}$, than of $\boldsymbol{2}_{\text {ads }}$ itself.

The plots of $\mathrm{k}_{\mathrm{app}} \mathrm{vs} \mathrm{n}_{\mathbf{1}}$ gave a straight line with the significant slope passing through the near origin at $0 \sim 0.8$ eq of Oxone. This suggests that $\mathrm{O}_{2}$ evolution is seconder order with respect to $\mathbf{1}_{\text {ads }}$ (Figure $10 \mathrm{~B}$ ), being similar to the $\mathrm{KMnO}_{4}$-treated system. At $0.8 \sim 1.4$ 
eq of Oxone, $\mathrm{k}_{\text {app }}$ was independent with $\mathrm{n}_{1}$, suggesting that $\mathrm{O}_{2}$ evolution is a first order with respect to adsorbed $\mathbf{1}_{\text {ads }}$. Under these conditions, $\mathbf{1}_{\text {ads }}$ and $\boldsymbol{2}_{\text {ads }}$ co-exist on mica because the mica adsorbate was prepared from the solution containing $\mathbf{1}$ and $\mathbf{2}$. The first order $\mathrm{O}_{2}$ evolution with respect to $\mathbf{1}_{\text {ads }}$ could be explained by cooperative catalysis of $\mathbf{1}_{\text {ads }}$ with $\mathbf{2}_{\text {ads }}$. This means that $\mathbf{1}_{\text {ads }}$ can work for the catalysis cooperatively with not only $\mathbf{1}_{\text {ads }}$ but also $\boldsymbol{2}_{\text {ads, }}$ although $\boldsymbol{2}_{\text {ads }}$ does not induce the catalytic activity alone. During the catalysis, $\mathbf{1}_{\text {ads }}$ is oxidized to $\boldsymbol{2}_{\text {ads, }}$, which could predominantly work for cooperative catalysis prior to relatively slow conversion to inactive species.

For the $\mathrm{Ce}(\mathrm{IV})$-treated system, the plots of $\mathrm{v}_{\mathrm{O} 2}$ vs the amount of $\mathrm{Ce}(\mathrm{IV})$ are added in Figure 7. The $\mathrm{v}_{\mathrm{O} 2}$ is very low under the conditions employed $\left(0.64 \mu \mathrm{mol} \mathbf{1}_{\mathrm{ads}}\right.$ on $10 \mathrm{mg}$ mica) although the significant amount of $\mathrm{O}_{2}$ was observed under the similar $\mathbf{1}_{\text {ads }}$ concentration conditions for $\mathrm{KMnO}_{4}$ - and Oxone-treated systems. Penetration of $\mathrm{Ce}(\mathrm{IV})$ ions (as an oxidant for water oxidation) into mica could be impeded by $\mathrm{Ce}^{3+}$ cations (generated in oxidative dimerization of $\mathbf{1}^{\prime}$ ) co-adsorbed with $\mathbf{1}_{\text {ads }}$ in the mica adsorbates to give low $\mathrm{v}_{\mathrm{O} 2}$ for the $\mathrm{Ce}(\mathrm{IV})$-treated system. This is supported by our earlier report in which $\mathrm{v}_{\mathrm{O} 2}$ for mica adsorbates containing $\mathbf{1}_{\text {ads }}$ (prepared using isolated 1) drastically decreased when trications such as $\mathrm{Al}^{3+}$ or $\mathrm{Ce}^{3+}$ are co-adsorbed (or post-adsorbed), although $\mathrm{v}_{\mathrm{O} 2}$ did not change when $\mathrm{Mg}^{2+}$ or $\mathrm{Ba}^{2+}$ dications are co-adsorbed.

\section{Conclusions.}

The oxidative dimerization reaction 1' stoichiometrically proceeded to from $\mathbf{1}$ when a $\mathrm{KMnO}_{4}$ oxidant was used. The subsequent oxidation of formed $\mathbf{1}$ to $\mathbf{2}$ following oxidative dimerization reaction of $\mathbf{1}$ ' was observed when Oxone and $\mathrm{Ce}(\mathrm{IV})$ oxidants are used. $\mathrm{KMnO}_{4}$ is a favorable oxidant for high yield (145\%) of $\mathbf{1}$ formation. The 
heterogeneous water oxidation catalyses by the mica adsorbates containing different composition of manganese species were examined. 1' and $\mathbf{2}_{\text {ads }}$ did not induce the catalysis activity alone, whereas $\mathbf{1}_{\text {ads }}$ worked for the catalysis through cooperation with adjacent $\mathbf{1}_{\mathrm{ads}}$ or $\mathbf{2}_{\mathrm{ads}}$. The recent X-ray absorption spectroscopic study of montmorillonite adsorbing 1 remind us the possibility of conversion of $\mathbf{1}_{\text {ads }}$ to the manage oxides as active catalysts during the catalysis[44]. However, the significantly dependent catalytic activity of manganese complex-based mica adsorbates on manganese species adsorbed could be difficult to be explained by simple formation of manganese oxides. It is most likely that $\mathbf{1}_{\mathrm{ads}}$ on works as the manganese cluster-based catalyst for water oxidation rather than manganese oxide.

\section{Acknowledgment.}

Research was supported by JST PRESTO program and Grant-in-Aid for Scientific Research (B) from the Ministry of Education, Culture, Sports, Science and Technology (No. 24350028).

\section{References}

[1] A. Zouni, H.T. Witt, J. Kern, P. Fromme, N. Krauss, W. Saenger, P. Orth, Crystal structure of photosystem II from Synechococcus elongatus at $3.8 \AA$ resolution, Nature, 409 (2001) 739-743.

[2] N. Kamiya, J.-R. Shen, Crystal structure of oxygen-evolving photosystem II from Thermosynechococcus vulcanus at 3.7-Å resolution, Proc. Natl. Acad. Sci. U. S. A., 100 (2003) 98-103. 
[3] K.N. Ferreira, T.M. Iverson, K. Maghlaoui, J. Barber, S. Iwata, Architecture of the Photosynthetic Oxygen-Evolving Center, Science, 303 (2004) 1831-1838.

[4] B. Loll, J. Kern, W. Saenger, A. Zouni, J. Biesiadka, Towards complete cofactor arrangement in the $3.0 \AA$ resolution structure of photosystem II, Nature, 438 (2005) 1040-1044.

[5] Y. Umena, K. Kawakami, J.-R. Shen, N. Kamiya, Crystal structure of oxygen-evolving photosystem II at a resolution of $1.9 \AA$, Nature, 473 (2011) 55-60.

[6] J.H. Robblee, R.M. Cinco, V.K. Yachandra, X-ray spectroscopy-based structure of the Mn cluster and mechanism of photosynthetic oxygen evolution, Biochim. Biophys. Acta Bioenerg., 1503 (2001) 7-23.

[7] J. Yano, J. Kern, K. Sauer, M.J. Latimer, Y. Pushkar, J. Biesiadka, B. Loll, W. Saenger, J. Messinger, A. Zouni, V.K. Yachandra, Where Water Is Oxidized to Dioxygen: Structure of the Photosynthetic $\mathrm{Mn}_{4} \mathrm{Ca}$ Cluster, Science, 314 (2006) $821-825$.

[8] M. Suga, F. Akita, K. Hirata, G. Ueno, H. Murakami, Y. Nakajima, T. Shimizu, K. Yamashita, M. Yamamoto, H. Ago, J.R. Shen, Native structure of photosystem II at $1.95 \AA$ Å resolution viewed by femtosecond X-ray pulses, Nature, 517 (2015) 99-103.

[9] W.F. Ruettinger, C. Campana, G.C. Dismukes, Synthesis and characterization of $\mathrm{Mn}_{4} \mathrm{O}_{4} \mathrm{~L}_{6}$ complexes with cubane-like core structure: A new class of models of the active site of the photosynthetic water oxidase, J. Am. Chem. Soc., 119 (1997) 6670-6671.

[10] C.E. Dube, D.W. Wright, S. Pal, P.J. Bonitatebus, W.H. Armstrong, Tetranuclear manganese-ore aggregates relevant to the photosynthetic water oxidation center. Crystal structure, spectroscopic properties and reactivity of adamantane-shaped 
$\left[\mathrm{Mn}_{4} \mathrm{O}_{6}(\text { bpea })_{4}\right]^{4+}$ and the reduced mixed-valence analog $\left[\mathrm{Mn}_{4} \mathrm{O}_{6}(\text { bpea })_{4}\right]^{3+}$, J. Am. Chem. Soc., 120 (1998) 3704-3716.

[11] H.-L.T. Sheyi Wang, Eduardo Libby, Kirsten Folting, William E. Streib, David N. Hendrickson, and George Christou, Modeling the Photosynthetic Water Oxidation Center: Chloride/Bromide Incorporation and Reversible Redox Processes in the Complexes $\mathrm{Mn}_{4} \mathrm{O}_{3} \mathrm{X}(\mathrm{OAc})_{3}(\mathrm{dbm})_{3}(\mathrm{X}=\mathrm{Cl}, \mathrm{Br})$ and $(\mathrm{pyH})_{3}\left[\mathrm{Mn}_{4} \mathrm{O}_{3} \mathrm{Cl}_{7}(\mathrm{OAc})_{3}\right]$, Inorg. Chem., 35 (1996) 7578-7589.

[12] G. Aromi, M.W. Wemple, S.J. Aubin, K. Folting, D.N. Hendrickson, G. Christou, Modeling the photosynthetic water oxidation complex: Activation of water by controlled deprotonation and incorporation into a tetranuclear manganese complex, J. Am. Chem. Soc., 120 (1998) 5850-5851.

[13] C. Philouze, G. Blondin, J.-J. Girerd, J. Guilhem, C. Pascard, D. Lexa, Aqueous Chemistry of High-Valent Manganese. Structure, Magnetic, and Redox Properties of a New Type of Mn-Oxo Cluster, $\left[\mathrm{Mn}^{\mathrm{IV}}{ }_{4} \mathrm{O}_{4}(\mathrm{bpy})_{6}\right]^{4+}$ : Relevance to the Oxygen Evolving Center in Plants, J. Am. Chem. Soc., 116 (1994) 8557-8565.

[14] J.B. Vincent, C. Christmas, H.R. Chang, Q. Li, P.D.W. Boyd, J.C. Huffman, D.N. Hendrickson, G. Christou, Modeling the photosynthetic water oxidation center. Preparation and properties of tetranuclear manganese complexes containing $\left[\mathrm{Mn}_{4} \mathrm{O}_{2}\right]^{6+, 7+, 8+}$ cores, and the crystal structures of $\mathrm{Mn}_{4} \mathrm{O}_{2}\left(\mathrm{O}_{2} \mathrm{CMe}\right)_{6}(\text { bipy })_{2}$ and $\left[\mathrm{Mn}_{4} \mathrm{O}_{2}\left(\mathrm{O}_{2} \mathrm{CMe}\right)_{7}(\text { bipy })_{2}\right]\left(\mathrm{ClO}_{4}\right)$, J. Am. Chem. Soc., 111 (1989) 2086-2097.

[15] V.K. Yachandra, V.J. Derose, M.J. Latimer, I. Mukerji, K. Sauer, M.P. Klein, Where Plants Make Oxygen - a Structural Model For the Photosynthetic Oxygen-Evolving Manganese Cluster, Science, 260 (1993) 675-679. 
[16] R. Manchanda, G.W. Brudvig, R.H. Crabtree, High-Valent Oxomanganese Clusters Structural and Mechanistic Work Relevant to the Oxygen-Evolving Center in Photosystem II, Coord. Chem. Rev., 144 (1995) 1-38.

[17] T.G. Carrell, A.M. Tyryshkin, G.C. Dismukes, An evaluation of structural models for the photosynthetic water-oxidizing complex derived from spectroscopic and X-ray diffraction signatures, J. Biol. Inorg. Chem., 7 (2002) 2-22.

[18] V.K. Yachandra, K. Sauer, M.P. Klein, Manganese cluster in photosynthesis: Where plants oxidize water to dioxygen, Chem. Rev., 96 (1996) 2927-2950.

[19] A.J. Wu, J.E. Penner-Hahn, V.L. Pecoraro, Structural, Spectroscopic, and Reactivity Models for the Manganese Catalases, Chem. Rev., 104 (2004) 903-938.

[20] S. Mukhopadhyay, S.K. Mandal, S. Bhaduri, W.H. Armstrong, Manganese Clusters with Relevance to Photosystem II, Chem. Rev., 104 (2004) 3981-4026.

[21] C.S. Mullins, V.L. Pecoraro, Reflections on small molecule manganese models that seek to mimic photosynthetic water oxidation chemistry, Coord. Chem. Rev., 252 (2008) 416-443.

[22] J. Limburg, J.S. Vrettos, L.M. Liable-Sands, A.L. Rheingold, R.H. Crabtree, G.W. Brudvig, A functional model for $\mathrm{O}-\mathrm{O}$ bond formation by the $\mathrm{O}_{2}$-evolving complex in photosystem II, Science, 283 (1999) 1524-1527.

[23] J. Limburg, J.S. Vrettos, H.Y. Chen, J.C. de Paula, R.H. Crabtree, G.W. Brudvig, Characterization of the $\mathrm{O}_{2}$-evolving reaction catalyzed by $\left[(\right.$ terpy $)\left(\mathrm{H}_{2} \mathrm{O}\right) \mathrm{Mn}^{\mathrm{III}} \mathrm{O}_{2} \mathrm{Mn}^{\mathrm{IV}}\left(\mathrm{OH}_{2}\right)($ terpy) $]\left(\mathrm{NO}_{3}\right)_{3}$ (terpy = 2,2 ': 6',2 "-terpyridine), J. Am. Chem. Soc., 123 (2001) 423-430.

[24] Y. Naruta, M. Sasayama, T. Sasaki, Oxygen Evolution by Oxidation of Water with Manganese Porphyrin Dimers, Angew. Chem. Int. Ed. Engl., 33 (1994) 1839-1841. 
[25] Y. Shimazaki, T. Nagano, H. Takesue, B.-H. Ye, F. Tani, Y. Naruta, Characterization of a Dinuclear $\mathrm{Mn}^{\mathrm{V}}=\mathrm{O}$ Complex and Its Efficient Evolution of $\mathrm{O}_{2}$ in the Presence of Water, Angew. Chem. Int. Ed., 43 (2004) 98-100.

[26] M. Yagi, K. Narita, Catalytic $\mathrm{O}_{2}$ Evolution from Water Induced by Adsorption of $\left[\left(\mathrm{OH}_{2}\right)(\mathrm{Terpy}) \mathrm{Mn}(\mu-\mathrm{O})_{2} \mathrm{Mn}(\mathrm{Terpy})\left(\mathrm{OH}_{2}\right)\right]^{3+}$ Complex onto Clay Compounds, J. Am. Chem. Soc., 126 (2004) 8084-8085.

[27] A.K. Poulsen, A. Rompel, C.J. McKenzie, Water oxidation catalyzed by a dinuclear Mn complex: A functional model for the oxygen-evolving center of photosystem II, Angew. Chem. Int. Ed., 44 (2005) 6916-6920.

[28] W. Ruettinger, M. Yagi, K. Wolf, S. Bernasek, G.C. Dismukes, $\mathrm{O}_{2}$ Evolution from the Manganese-Oxo Cubane Core $\mathrm{Mn}_{4} \mathrm{O}_{4}{ }^{6+}$ : A Molecular Mimic of the Photosynthetic Water Oxidation Enzyme?, J. Am. Chem. Soc., 122 (2000) 10353-10357.

[29] R. Brimblecombe, A. Koo, G.C. Dismukes, G.F. Swiegers, L. Spiccia, Solar Driven Water Oxidation by a Bioinspired Manganese Molecular Catalyst, J. Am. Chem. Soc., 132 (2010) 2892-2894.

[30] E.A. Karlsson, B.-L. Lee, T. Åkermark, E.V. Johnston, M.D. Kärkäs, J. Sun, Ö. Hansson, J.-E. Bäckvall, B. Åkermark, Photosensitized Water Oxidation by Use of a Bioinspired Manganese Catalyst, Angew. Chem. Int. Ed., 50 (2011) 11715-11718.

[31] X. Liu, F. Wang, Transition metal complexes that catalyze oxygen formation from water: 1979-2010, Coord. Chem. Rev., 256 (2012) 1115-1136.

[32] R. Cao, W. Laia, P. Du, Catalytic water oxidation at single metal sites, Energy Environ. Sci., 5 (2012) 8134-8157. 
[33] E.S. Andreiadis, M. Chavarot-Kerlidou, M. Fontecave, V. Artero, Artificial photosynthesis: from molecular catalysts for light-driven water splitting to photoelectrochemical cells, Photochem. Photobiol., 87 (2011) 946-964.

[34] V. Artero, M. Fontecave, Solar fuels generation and molecular systems: is it homogeneous or heterogeneous catalysis? , Chem. Soc. Rev., 42 (2013) 2338-2356.

[35] M.-N. Collomb, A. Deronzier, Electro- and Photoinduced Formation and Transformation of Oxido-Bridged Multinuclear Mn Complexes, Eur. J. Inorg. Chem., 2009 (2009) 2025-2046.

[36] M. Yagi, A. Syouji, S. Yamada, M. Komi, H. Yamazaki, S. Tajima, Molecular catalysts for water oxidation toward artificial photosynthesis, Photochem. Photobiol. Sci., 8 (2009) 139-147.

[37] M. Wiechen, H.-M. Berendsa, P. Kurz, Water oxidation catalysed by manganese compounds: from complexes to ‘biomimetic rocks’ Dalton Trans., 41 (2012) 21-31.

[38] R. Ramaraj, A. Kira, M. Kaneko, Heterogeneous water oxidation by a dinuclear manganese complex, Chem. Lett., (1987) 261-264.

[39] R. Ramaraj, A. Kira, M. Kaneko, $\mathrm{O}_{2}$-generation by oxidation of water with di- and trinuclear ruthenium complexes as homogeneous and heterogeneous catalysts, Angew. Chem. Int. Ed. Engl., 25 (1986) 1009-1011.

[40] K. Narita, T. Kuwabara, K. Sone, K. Shimizu, M. Yagi, Characterization and activity analysis of catalytic water oxidation induced by hybridization of $\left[\left(\mathrm{OH}_{2}\right)(\text { terpy }) \mathrm{Mn}(\mu-\mathrm{O})_{2} \mathrm{Mn}(\text { terpy })\left(\mathrm{OH}_{2}\right)\right]^{3+}$ and clay compounds, J. Phys. Chem. B, 110 (2006) 23107-23114.

[41] M. Yagi, K. Narita, S. Maruyama, K. Sone, T. Kuwabara, K.-i. Shimizu, Artificial model of photosynthetic oxygen evolving complex: Catalytic $\mathrm{O}_{2}$ production from 
water by di-m-oxo manganese dimers supported by clay compounds, Biochim. Biophys. Acta Bioenerg., 1767 (2007) 660-665.

[42] M. Yagi, M. Toda, S. Yamada, H. Yamazaki, An artificial model of photosynthetic photosystem II: visible-light-derived $\mathrm{O}_{2}$ production from water by a di- $\mu$-oxo-bridged manganese dimer as an oxygen evolving center, Chem. Commun., 46 (2010) 8594-8596.

[43] H. Yamazaki, S. Igarashi, T. Nagata, M. Yagi, Substituent Effects on Core Structures and Heterogeneous Catalytic Activities of $\mathrm{Mn}^{\text {III }}(\mu-\mathrm{O})_{2} \mathrm{Mn}^{\text {IV }}$ Dimers with 2,2':6',2"-Terpyridine Derivative Ligands for Water Oxidation, Inorg. Chem., 51 (2012) 1530-1539.

[44] M.M. Najafpour, A.N. Moghaddam, H. Dau, I. Zaharieva, Fragments of layered manganese oxide are the real water oxidation catalyst after transformation of molecular precursor on clay, J. Am. Chem. Soc., 136 (2014) 7245-7248.

[45] M.M. Najafpour, A.N. Moghaddam, Amorphous manganese oxide-coated montmorillonite as an efficient catalyst for water oxidation, New J. Chem., 36 (2012) 2514-2519.

[46] H. Chen, R. Tagore, S. Das, C. Incarvito, J.W. Faller, R.H. Crabtree, G.W. Brudvig, General Synthesis of Di- $\mu$-oxo Dimanganese Complexes as Functional Models for the Oxygen Evolving Complex of Photosystem II, Inorg. Chem., 44 (2005) $7661-7670$

[47] J. Limburg, V.A. Szalai, G.W. Brudvig, A mechanistic and structural model for the formation and reactivity of a $\mathrm{Mn}^{\mathrm{V}}=\mathrm{O}$ species in photosynthetic water oxidation, $\mathrm{J}$. Chem. Soc. Dalton Trans., (1999) 1353-1361. 
[48] C. Baffert, M.-N. Collomb, A. Deronzier, J. Pecaut, J. Limburg, R.H. Crabtree, G.W. Brudvig, Two New Terpyridine Dimanganese Complexes: A Manganese(III,III) Complex with a Single Unsupported Oxo Bridge and a Manganese(III,IV) Complex with a Dioxo Bridge. Synthesis, Structure, and Redox Properties, Inorg. Chem., 41 (2002) 1404-1411.

[49] M.N. Collomb, A. Deronzier, A. Richardot, J. Pecaut, Synthesis and characterization of a new kind of $\mathrm{Mn}_{2}{ }^{\text {III, IV }} \mu$-oxo complex: $\left[\mathrm{Mn}_{2} \mathrm{O}_{2}(\text { terpy })_{2}\left(\mathrm{H}_{2} \mathrm{O}\right)_{2}\right]\left(\mathrm{NO}_{3}\right)_{3} \cdot 6 \mathrm{H}_{2} \mathrm{O}$, terpy = 2,2':6',2"- terpyridine, New J. Chem., 23 (1999) 351-353.

[50] D.R. Gamelin, M.L. Kirk, T.L. Stemmler, S. Pal, W.H. Armstrong, J.E. Pennerhahn, E.I. Solomon, Electronic-Structure and Spectroscopy of Manganese Catalase and Di- $\mu-O x o \quad\left[\mathrm{Mn}^{\mathrm{III}} \mathrm{Mn}^{\mathrm{IV}}\right]$ Model Complexes, J. Am. Chem. Soc., 116 (1994) 2392-2399.

[51] S.R. Cooper, M. Calvin, Mixed Valence Interactions in Di- $\mu$-oxo Bridged Manganese Complexes, J. Am. Chem. Soc., 99 (1977) 6623-6630.

[52] H. Chen, J.W. Faller, R.H. Crabtree, G.W. Brudvig, Dimer-of-Dimers Model for the Oxygen-Evolving Complex of Photosystem II. Synthesis and Properties of $\left[\mathrm{Mn}_{4}{ }_{4} \mathrm{O}_{5}(\text { terpy })_{4}\left(\mathrm{H}_{2} \mathrm{O}\right)_{2}\right]\left(\mathrm{ClO}_{4}\right)_{6}$, J. Am. Chem. Soc., 126 (2004) 7345-7349.

[53] C. Baffert, S. Romain, A. Richardot, J.-C. Lepretre, B. Lefebvre, A. Deronzier, M.-N. Collomb, Electrochemical and Chemical Formation of $\left[\mathrm{Mn}_{4}{ }^{\mathrm{IV}} \mathrm{O}_{5}(\text { terpy })_{4}\left(\mathrm{H}_{2} \mathrm{O}\right)_{2}\right]^{6+}$, in Relation with the Photosystem II Oxygen-Evolving Center Model $\left[\mathrm{Mn}_{2}{ }^{\mathrm{III}, \mathrm{IV}} \mathrm{O}_{2}(\text { terpy })_{2}\left(\mathrm{H}_{2} \mathrm{O}\right)_{2}\right]^{3+}$, J. Am. Chem. Soc., 127 (2005) 13694-13704. 
Table 1 Summary of in situ formation yields of $\mathbf{1}$ and $\mathbf{2}$ from a 1' solution (1.0 mM, pH $=3.0$ ) and amounts (expressed as equivalence (eq)) of oxidant using various oxidants.

\begin{tabular}{ccccc}
\hline Oxidant & \multicolumn{3}{c}{ 1 yield (oxidant eq) } & 2 yield (oxidant eq) \\
\hline $\mathrm{KMnO}_{4}$ & $145 \%$ & $(0.5 \mathrm{eq})$ & \multicolumn{2}{c}{-} \\
Oxone & $87 \%$ & $(0.8 \mathrm{eq})$ & $91.4 \%$ & $(1.4 \mathrm{eq})$ \\
$\mathrm{Ce}(\mathrm{IV})$ & $67 \%$ & $(5.2 \mathrm{eq})$ & $74 \%$ & $(9.4 \mathrm{eq})$ \\
\hline
\end{tabular}




\section{Figure captions}

Figure 1A UV-Visible adsorption spectral change of a 1' solution $(1.0 \mathrm{mM}, \mathrm{pH}=3.0)$ in titration with a $\mathrm{KMnO}_{4}$ solution. The red spectrum is for the 1' solution. The green and purple spectral changes are due to formation of $\mathbf{1}$ and $\mathrm{KMnO}_{4}$ concentration increase, respectively.

Figure 1B Absorbance changes at $552(\circ)$ and $655(\mathbf{a}) \mathrm{nm}$ in titration of 1' solution (1.0 $\mathrm{mM}, \mathrm{pH}=3.0$ ) with a $\mathrm{KMnO}_{4}$ solution.

Figure 2 Distribution of manganese species $\left(\mathbf{1}^{\prime}(\square)\right.$ and $\left.\mathbf{1}(\bullet)\right)$ in an oxidative dimerization reaction of $\mathbf{1}^{\prime}(1.0 \mathrm{mM}, \mathrm{pH}=3.0)$, and initial rate $\left(v_{O 2}\left(\mathrm{~mol} \mathrm{~s}^{-1}\right)\right)$ of $\mathrm{O}_{2}$ evolution versus the amount of added $\mathrm{KMnO}_{4}$ for the $\mathrm{KMnO}_{4}$-treated system. The conditions for $\mathrm{O}_{2}$ evolution experiments are $50 \mathrm{mM} \mathrm{Ce(IV),} 2.0 \mathrm{~mol}$ (total $\mathrm{Mn}$ amount) / $10 \mathrm{mg}$ mica, $2.0 \mathrm{ml}$ liquid volume, $\mathrm{pH}=1.0$.

Figure 3A UV-Visible adsorption spectral change of 1' solution $(1.0 \mathrm{mM}, \mathrm{pH}=3.0)$ in titration with an Oxone solution. The red spectrum is for the 1' solution. The green and brown spectral changes are due to formation of $\mathbf{1}$ and $\mathbf{2}$, respectively.

Figure 3B Absorbance changes at $552(\circ)$ and $655(\mathbf{a}) \mathrm{nm}$ in titration of 1' solution (1.0 $\mathrm{mM}, \mathrm{pH}=3.0$ ) with an Oxone solution. 
Figure 4 UV-Visible adsorption spectra of the 1 solution $(0.5 \mathrm{mM}, \mathrm{pH}=3.0)$ before (green dot line) and after (red line) flow electrolysis (800 s) of (a) at $1.2 \mathrm{~V}$ vs $\mathrm{Ag} / \mathrm{AgCl}$ and $20.0 \mathrm{ml} \mathrm{min} \mathrm{m}^{-1}$ of the flow rate.

Figure 5 Distribution of manganese species $\left(\mathbf{1}^{\prime}(\square), \mathbf{1}(\bullet)\right.$ and $\left.2(\bullet)\right)$ in an oxidative dimerization reaction of $\mathbf{1}^{\prime}(1.0 \mathrm{mM}, \mathrm{pH}=3.0)$, and initial rate $\left(v_{O 2}\left(\mathrm{~mol} \mathrm{~s}^{-1}\right)\right)$ of $\mathrm{O}_{2}$ evolution versus the amount of added Oxone for the Oxone-treated system. The conditions for $\mathrm{O}_{2}$ evolution experiments are $50 \mathrm{mM} \mathrm{Ce(IV),} 2.0 \mathrm{~mol}$ (total $\mathrm{Mn}$ amount) / $10 \mathrm{mg}$ mica, $2.0 \mathrm{ml}$ liquid volume, $\mathrm{pH}=1.0$. The calculated $\mathrm{c}_{1}$, value includes $\sim 9 \%$ of the other manganese species particularly at the higher Oxone amounts.

Figure 6 UV-Visible adsorption spectral change of 1 ' solution $(1.0 \mathrm{mM}, \mathrm{pH}=3.0)$ in titration with a $\mathrm{Ce}(\mathrm{IV})$ solution. The red spectrum is for the 1' solution. The green and brown spectral changes are due to formation of $\mathbf{1}$ and $\mathbf{2}$, respectively.

Figure 7 Distribution of manganese species $\left(\mathbf{1}^{\prime}(\square), \mathbf{1}(\bullet)\right.$ and $\left.2(\bullet)\right)$ in an oxidative dimerization reaction of $\mathbf{1}^{\prime}(1.0 \mathrm{mM}, \mathrm{pH}=3.0)$, and initial rate $\left(v_{O 2}\left(\mathrm{~mol} \mathrm{~s}^{-1}\right)\right)$ of $\mathrm{O}_{2}$ evolution versus the amount of added Ce(IV) for the Ce(IV)-treated system. The conditions for $\mathrm{O}_{2}$ evolution experiments are $50 \mathrm{mM} \mathrm{Ce}(\mathrm{IV}), 2.0 \mathrm{~mol}$ (total $\mathrm{Mn}$ amount) / $10 \mathrm{mg}$ mica, $2.0 \mathrm{ml}$ liquid volume, $\mathrm{pH}=1.0$. The calculated $\mathrm{c}_{1}$, value includes at most $26 \%$ of the other manganese species particularly at the higher Ce(IV) amounts. 
Figure 8 UV-visible diffuse reflectance (DR) of the mica adsorbates prepared from the solution mainly containing 1 (treated with 0.8 eq Oxone) (green line) and prepared from the solution mainly containing $\mathbf{2}$ (treated with 1.4 eq Oxone) (blue line)

Figure 9 Plots of $\mathrm{k}_{\mathrm{app}}$ vs. the amount $\left(\mathrm{n}_{\mathbf{1}}\right)$ of complex $\mathbf{1}\left(\mathbf{1}_{\mathrm{ads}}\right)$ adsorbed onto mica for $\mathrm{KMnO}_{4}$-treated system (A) and Oxone-treated system (B). The amounts of oxidants added are indicated on figures. 


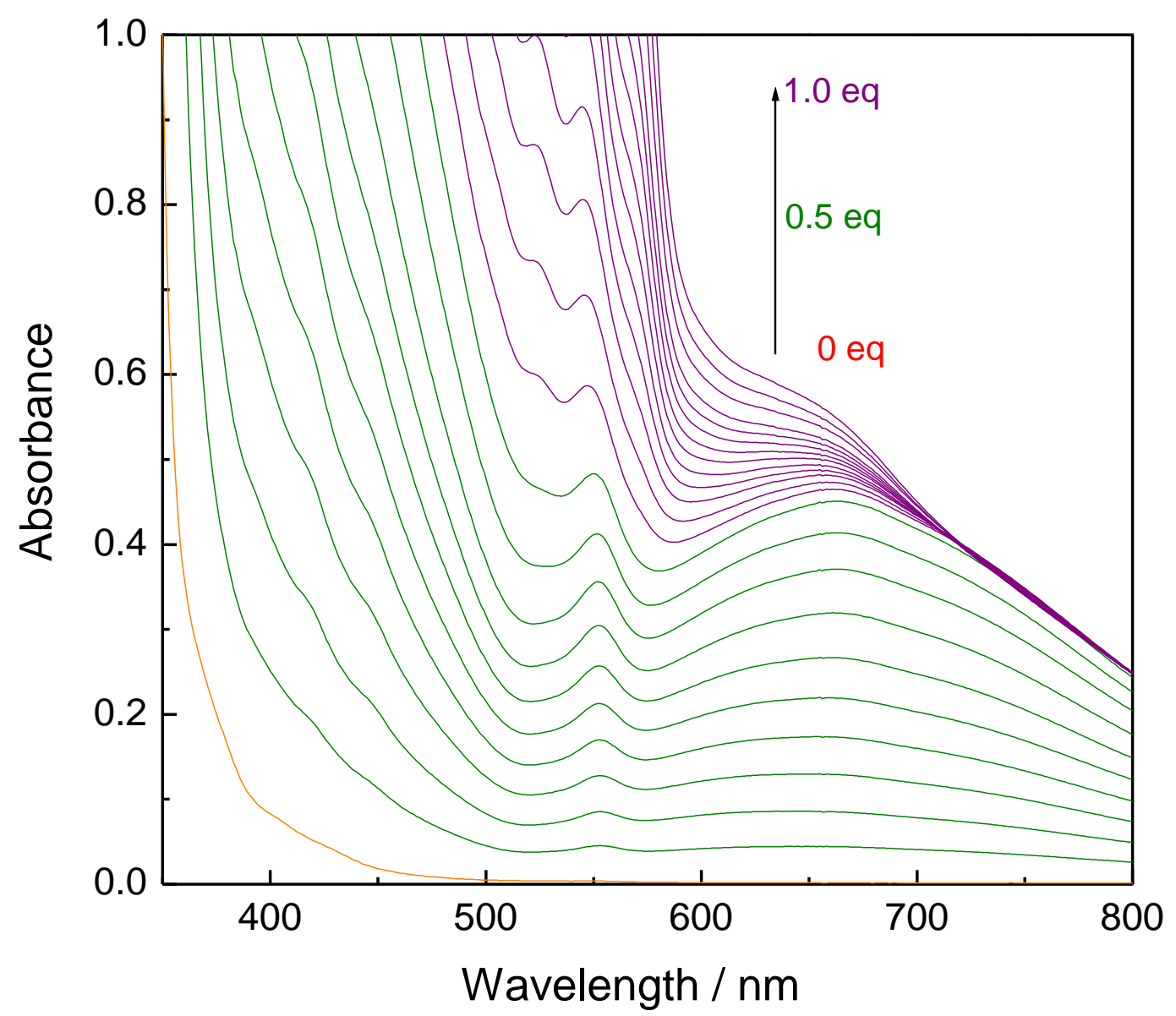

Figure 1A 


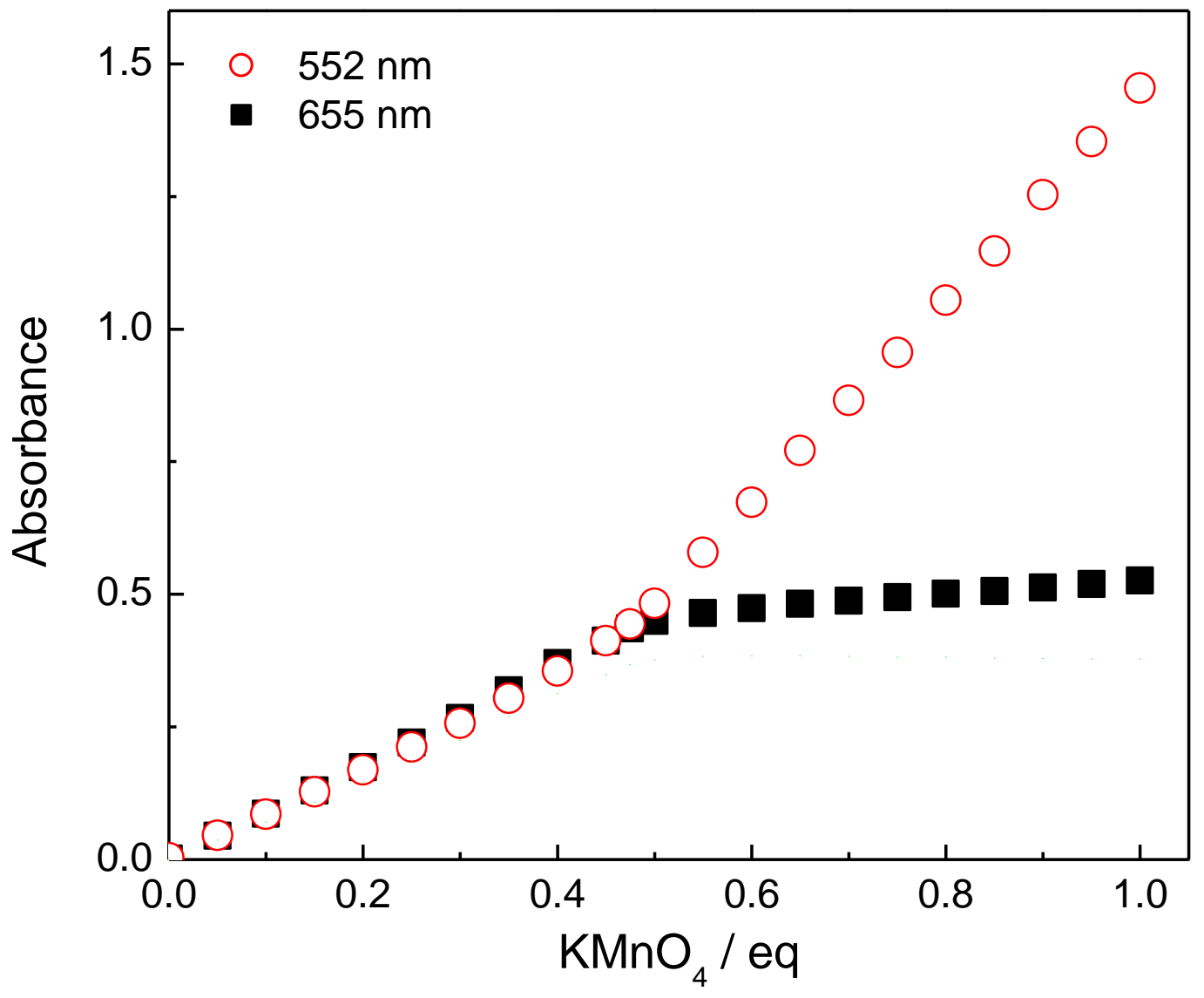

Figure 1B 


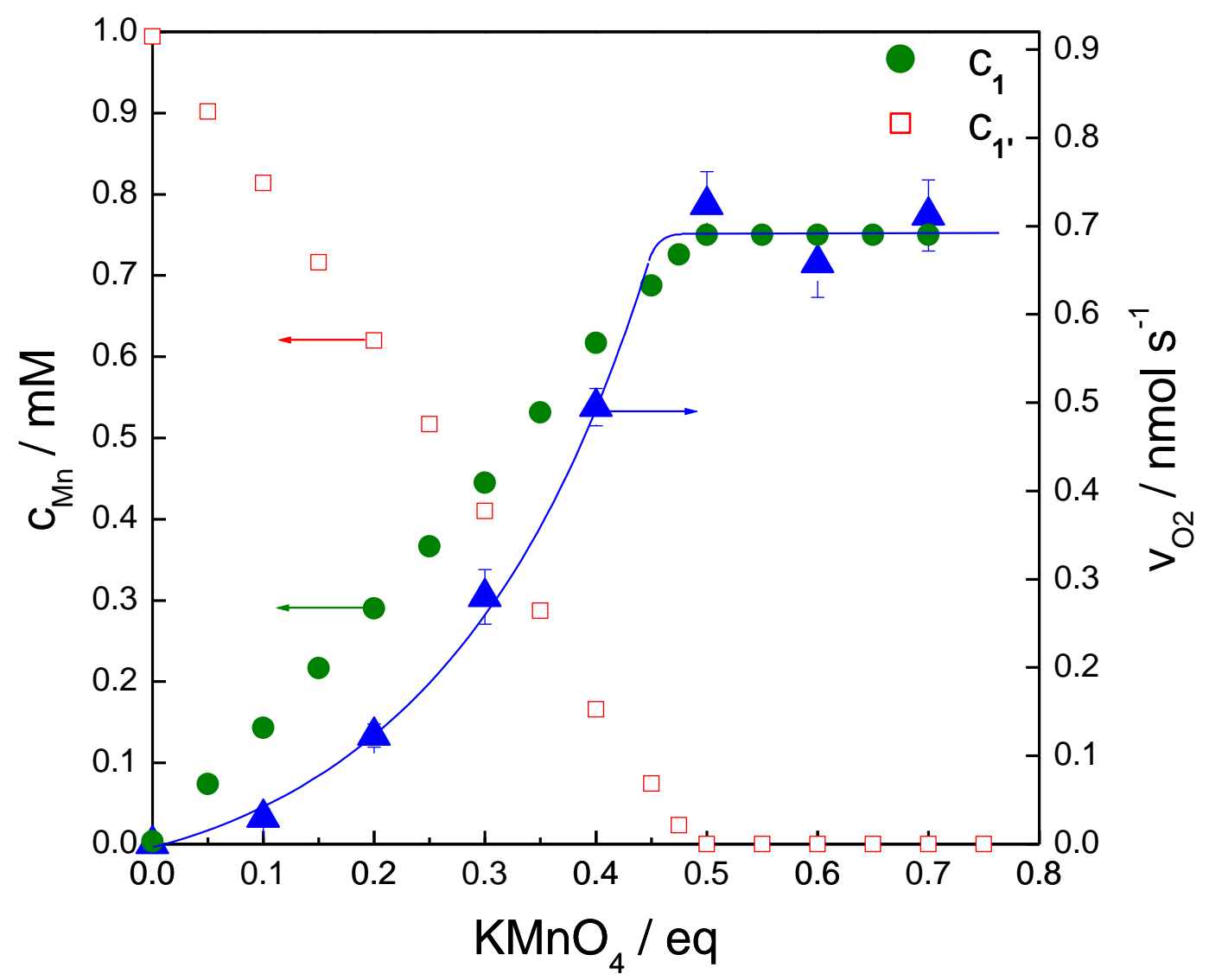

Figure 2 


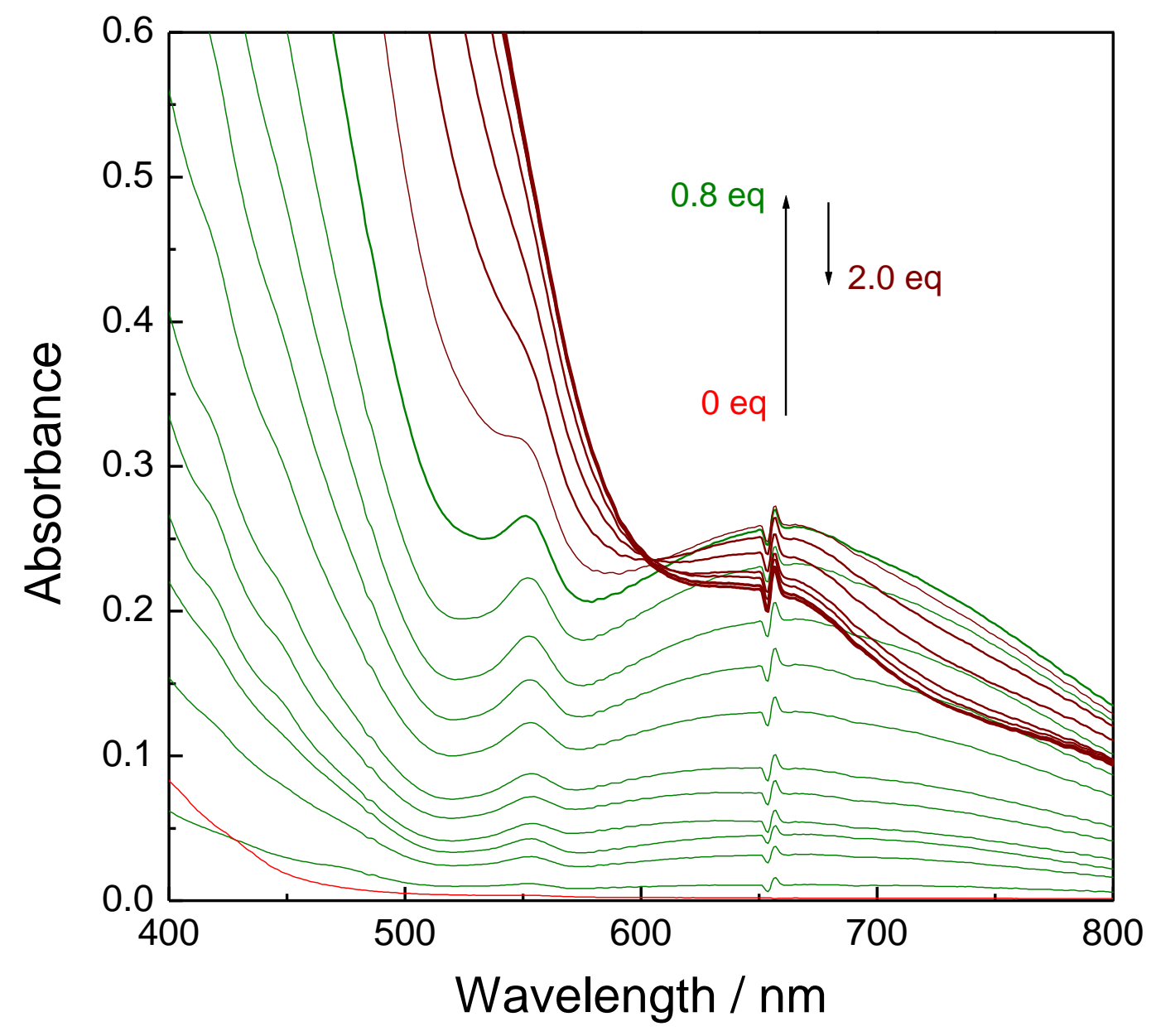

Figure 3A 


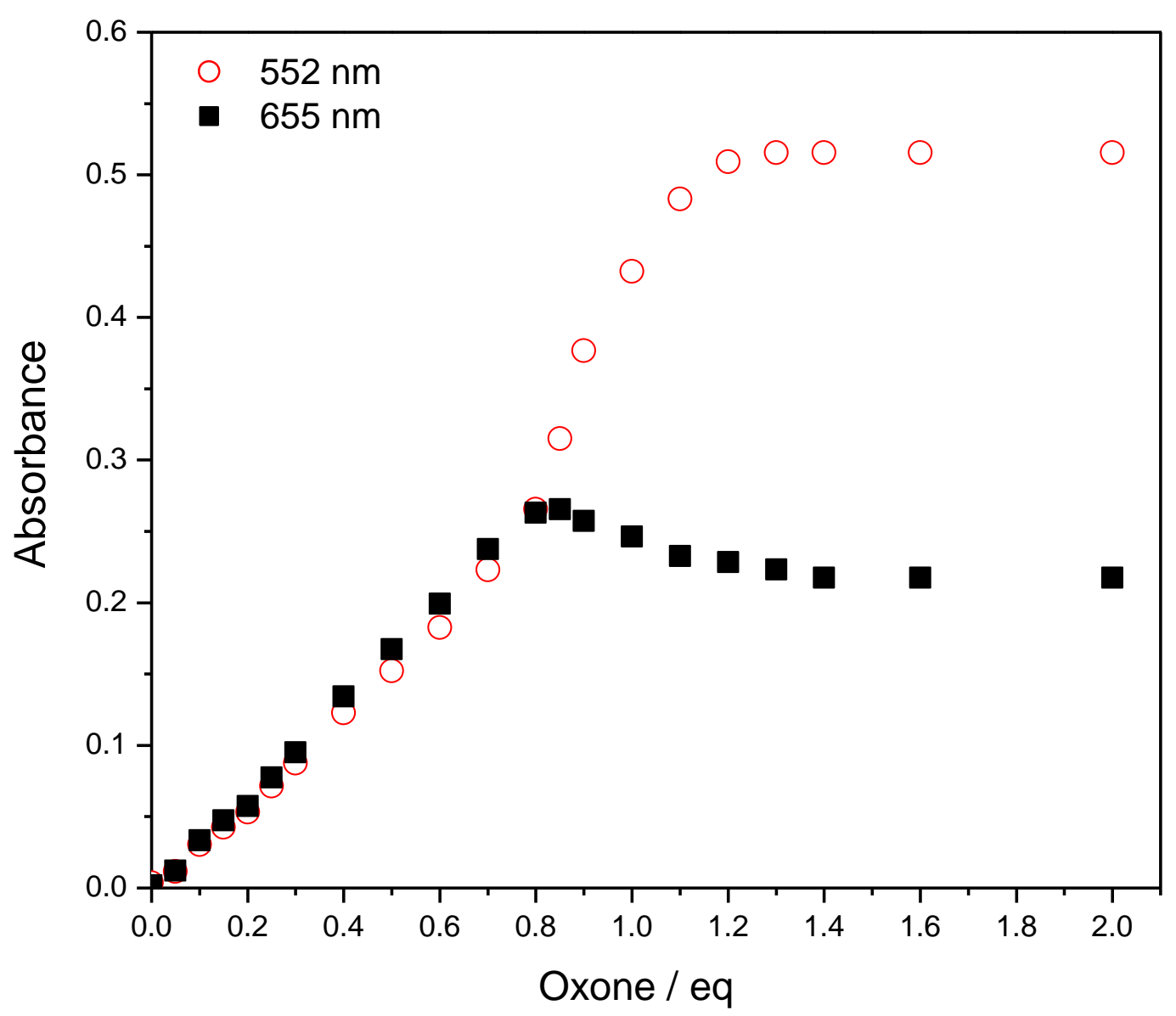

Figure 3B 


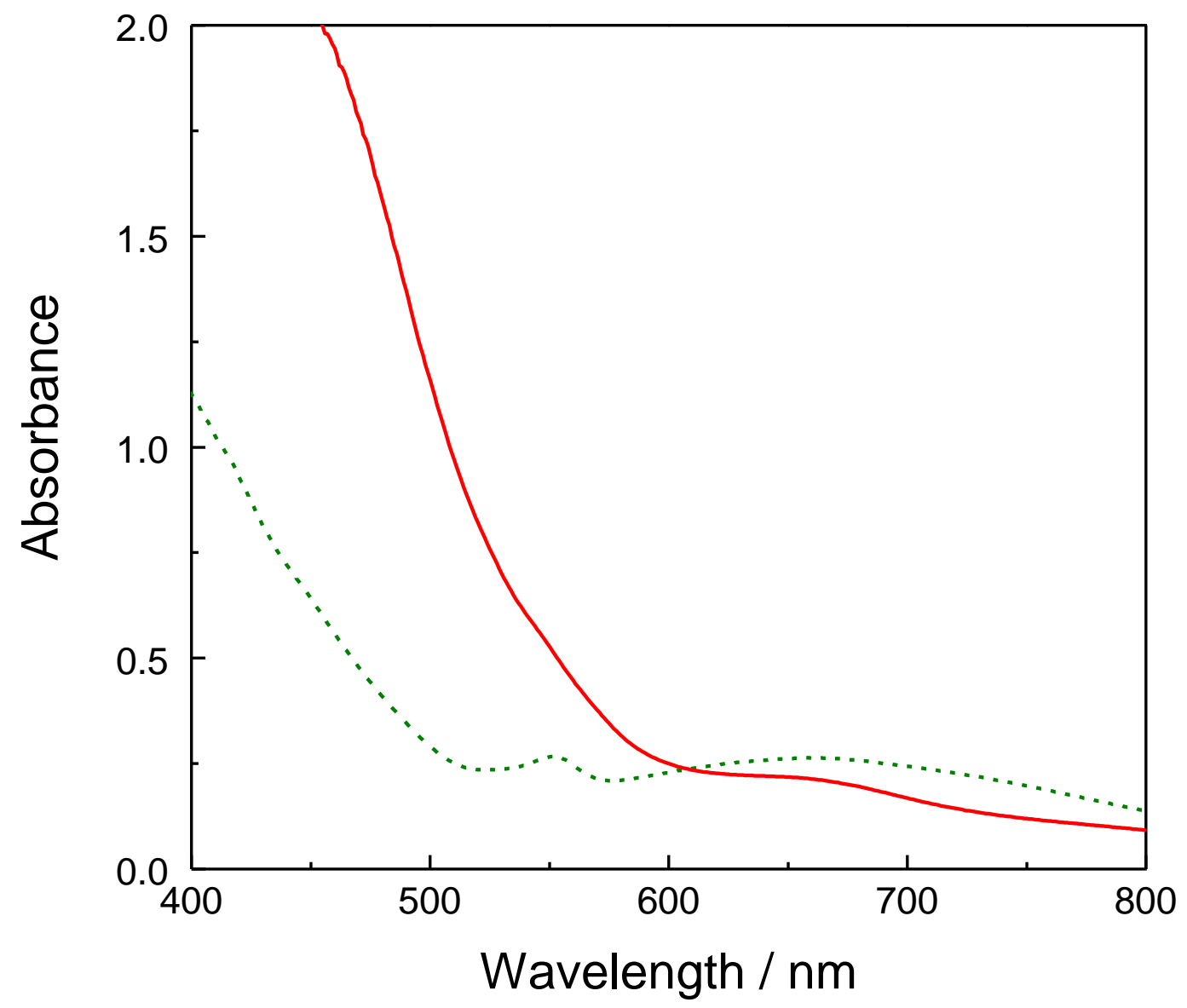

Figure 4 


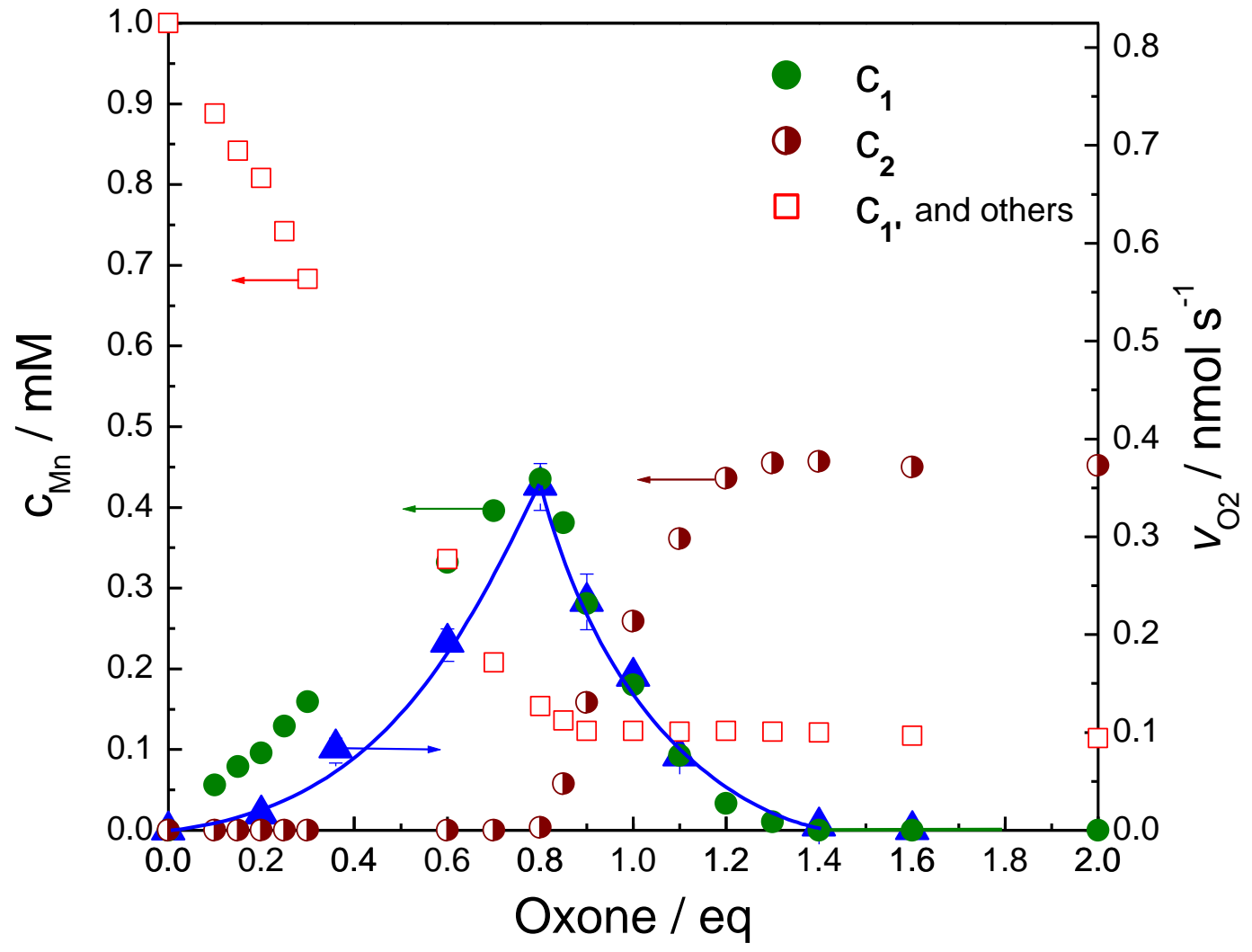

Figure 5 


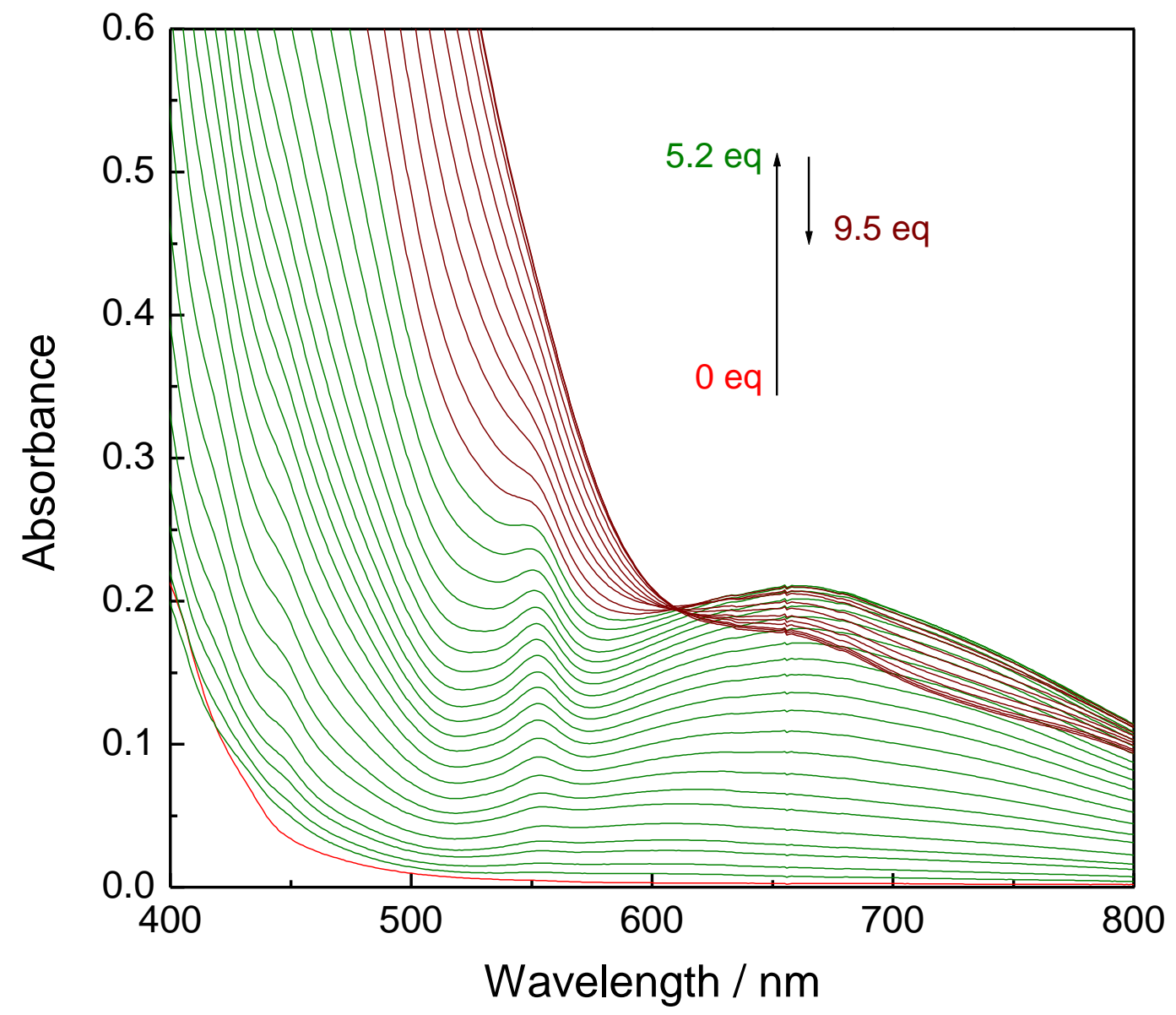

Figure 6 


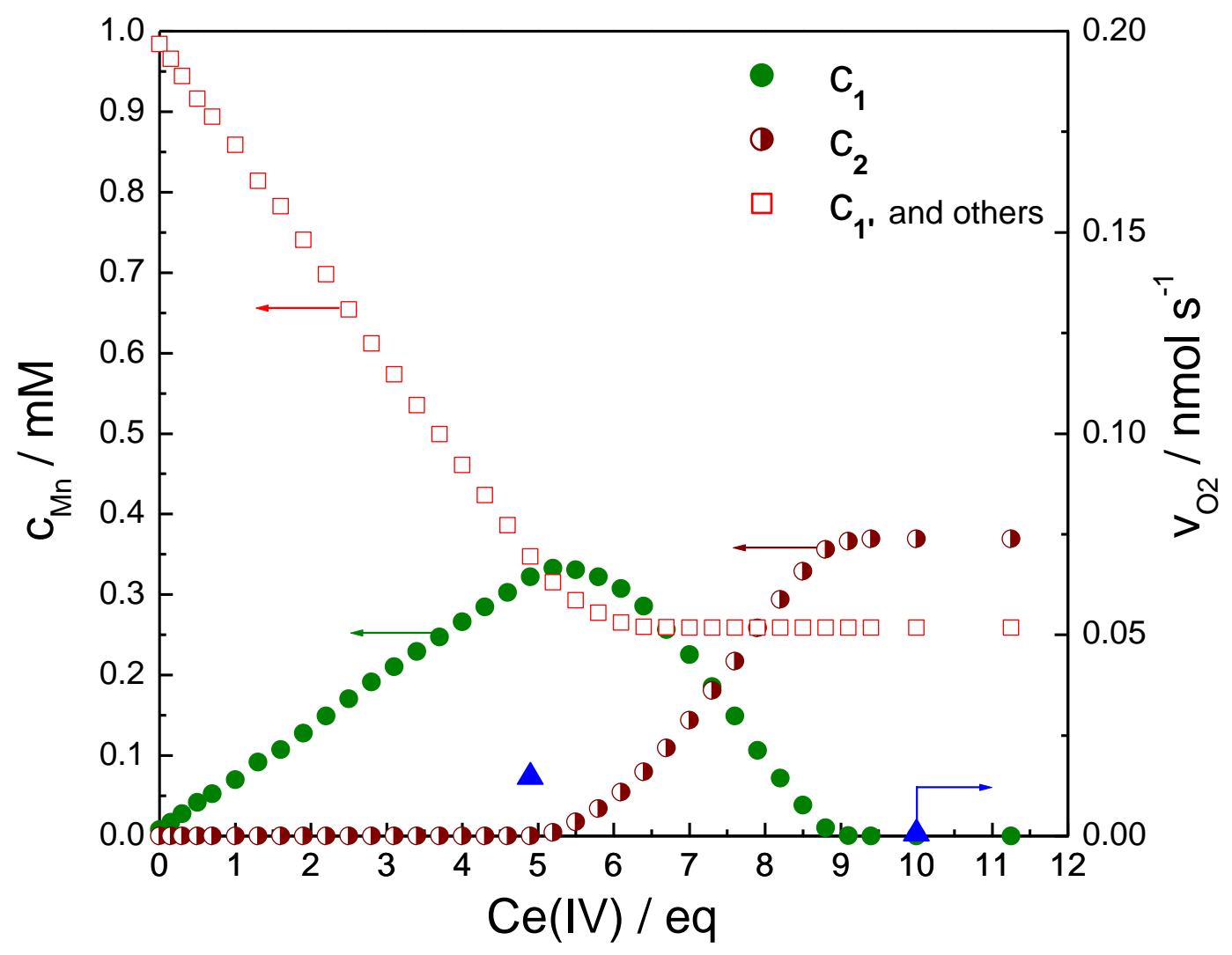

Figure 7 


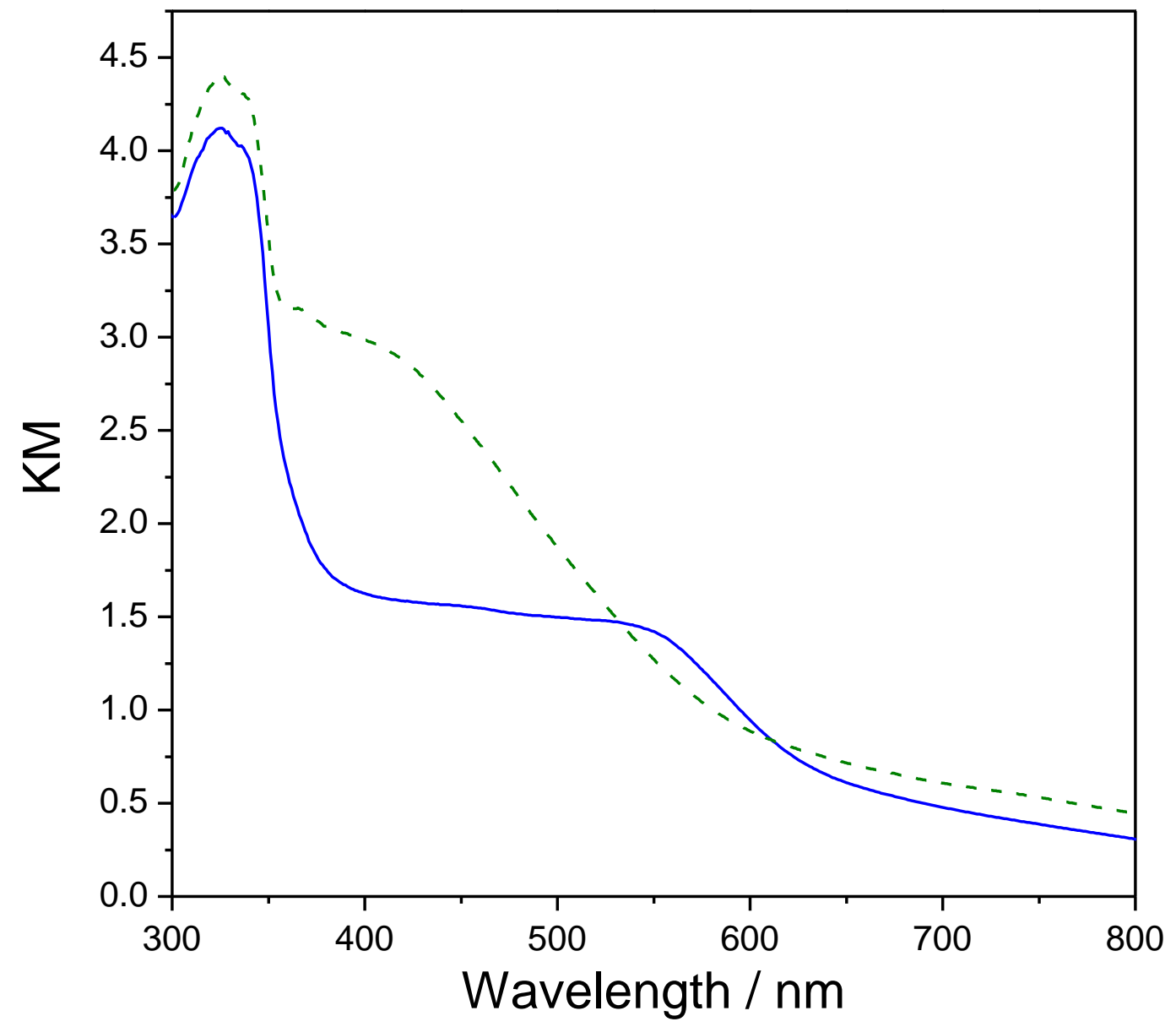

Figure 8 


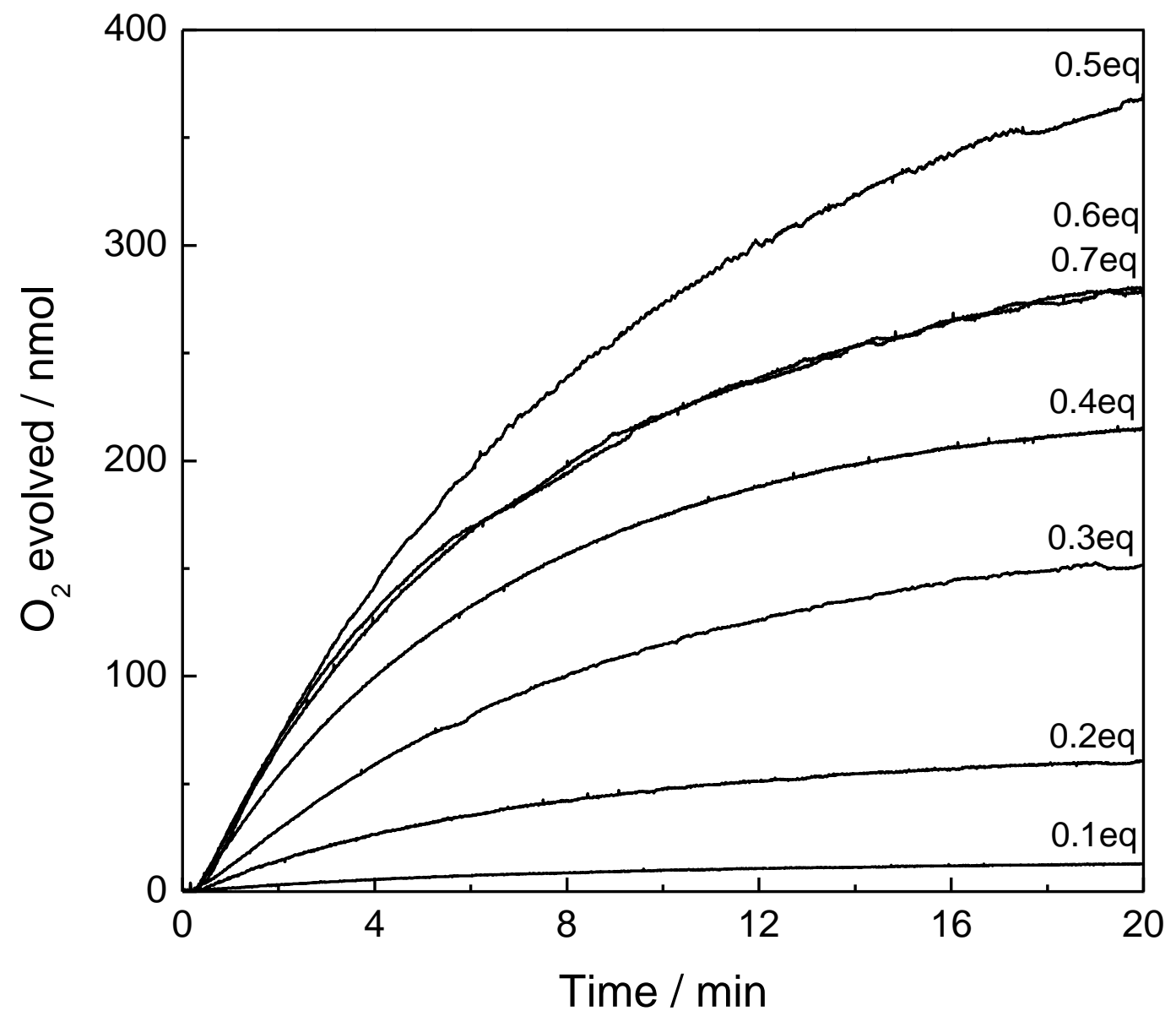

Figure 9 


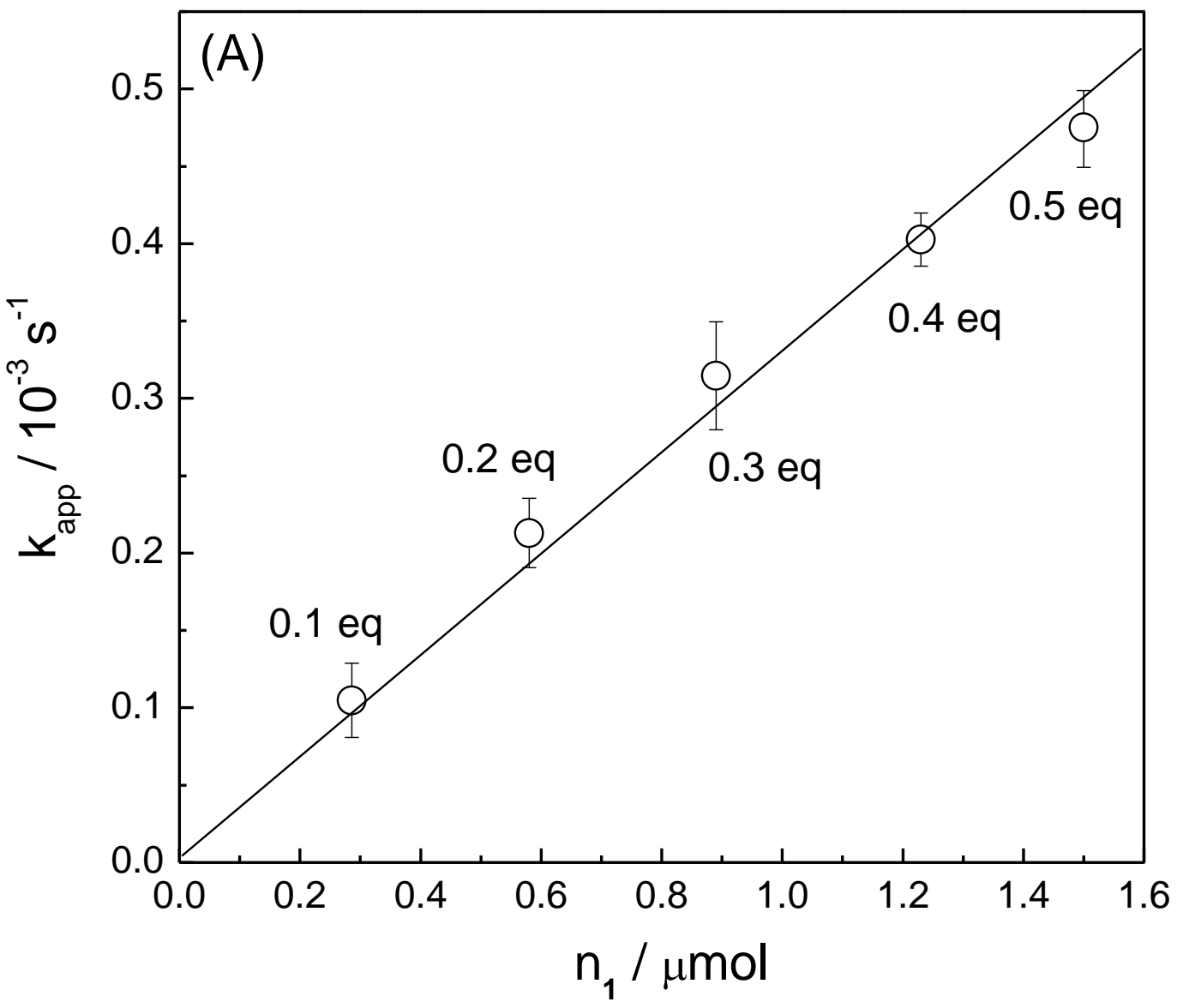

Figure 10A 


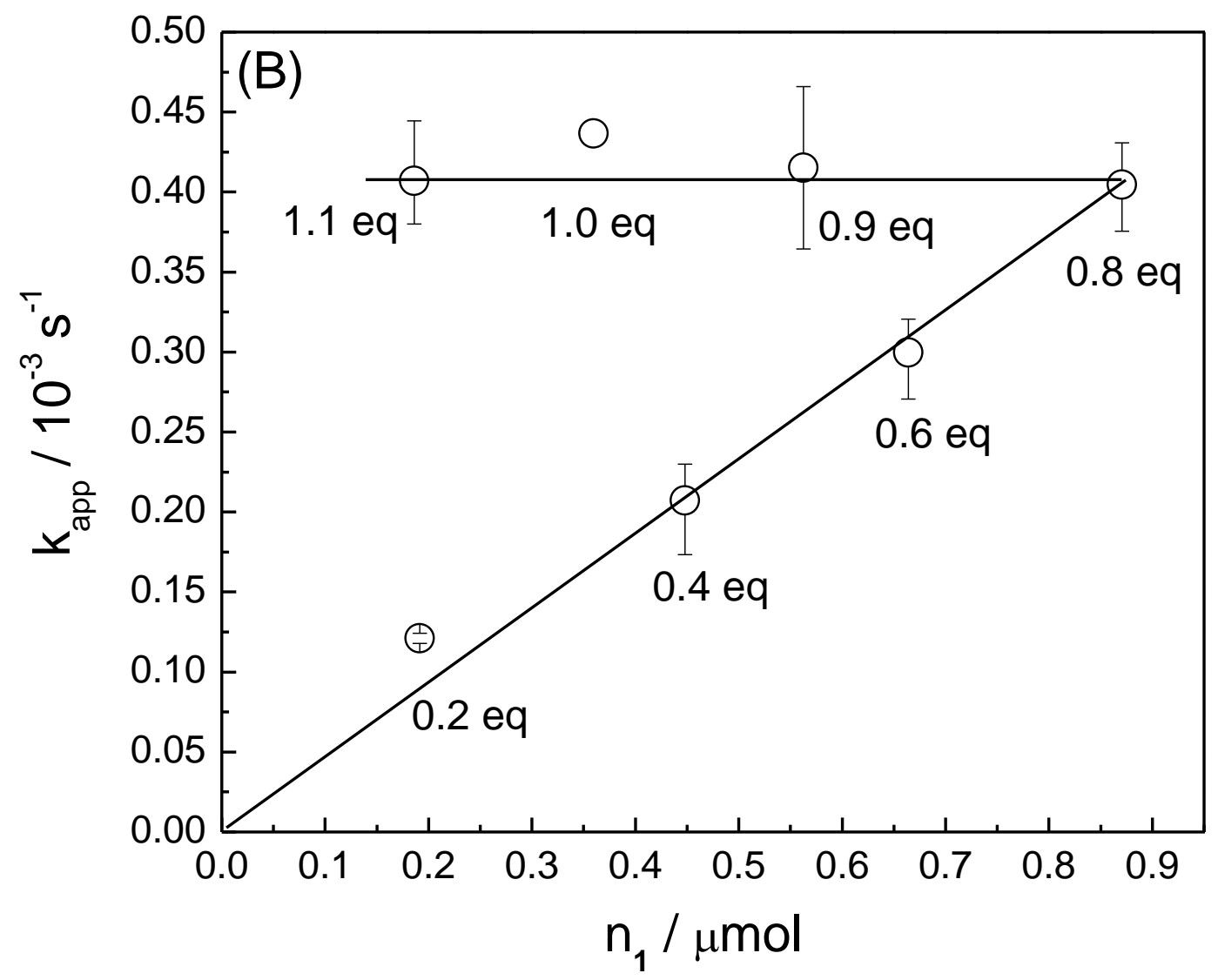

Figure 10B 


\section{Graphical Abstract}

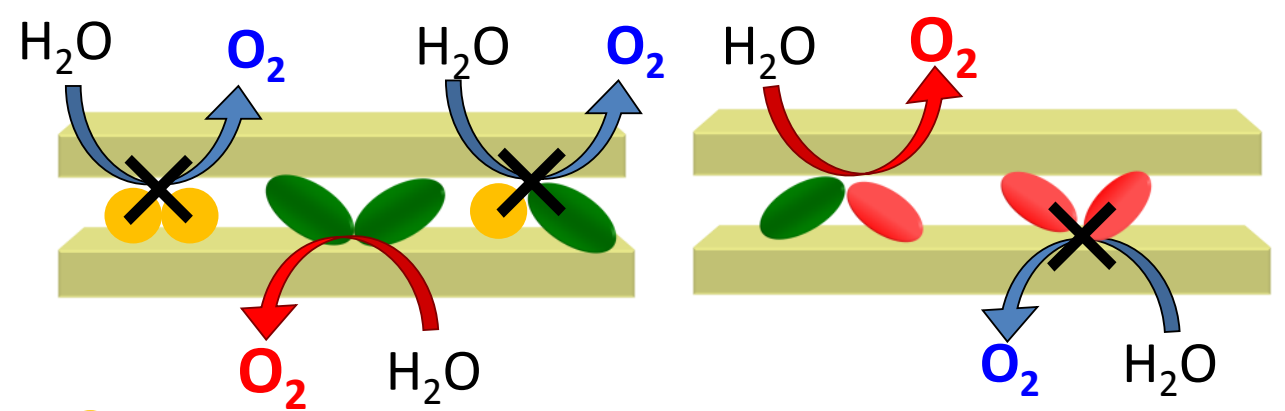

$:\left[\mathrm{Mn}^{\prime \prime}(\text { terpy })_{2}\right]^{2+}:\left[\left(\mathrm{OH}_{2}\right)(\text { terpy }) \mathrm{Mn}^{\mathrm{III}}(\mu-\mathrm{O})_{2} \mathrm{Mn}^{\mathrm{IV}}(\text { terpy })\left(\mathrm{OH}_{2}\right)\right]^{3+}$

$:\left[\left(\mathrm{OH}_{2}\right)(\text { terpy }) \mathrm{Mn}^{\mathrm{IV}}(\mu-\mathrm{O})_{2} \mathrm{Mn}^{\mathrm{IV}}(\text { terpy })\left(\mathrm{OH}_{2}\right)\right]^{4+}$ 